\title{
ARE HOUSING PRICE CYCLES ASYMMETRIC? EVIDENCE FROM THE US STATES AND METROPOLITAN AREAS
}

\author{
Christophe ANDRÉ ${ }^{1}$, Rangan GUPTA ${ }^{2,}$, John W. MUTEBA MWAMBA ${ }^{3}$ \\ ${ }^{1}$ Economics Department, Organisation for Economic Co-operation and Development (OECD), \\ 75775 Paris, Cedex 16, France \\ 2 Department of Economics, University of Pretoria, Pretoria, 0002, South Africa \\ ${ }^{3}$ Faculty of Economic and Financial Sciences, University of Johannesburg, P.O. Box 524, \\ Auckland Park 2006, South Africa
}

Received 16 April 2017; accepted 15 January 2018

\begin{abstract}
This paper investigates asymmetry in US housing price cycles at the state and metropolitan statistical area (MSA) level, using the Triples test (Randles, Flinger, Policello, \& Wolfe, 1980) and the Entropy test of Racine and Maasoumi (2007). Several reasons may account for asymmetry in housing prices, including non-linearity in their determinants and in behavioural responses, in particular linked to equity constraints and loss aversion. However, few studies have formally tested the symmetry of housing price cycles. We find that housing prices are asymmetric in the vast majority of cases. Taking into account the results of the two tests, deepness asymmetry, which represents differences in the magnitude of upswings and downturns, is found in 39 out of the 51 states (including the District of Columbia) and 238 out of the 381 MSAs. Steepness asymmetry, which measures differences in the speed of price changes during upswings and downturns, is found in 40 states and 257 MSAs. These results imply that linear models are in most cases insufficient to capture housing price dynamics.
\end{abstract}

Keywords: asymmetry, house prices, US economy.

\section{Introduction}

Housing market developments have played a major role in the Great Recession, the largest contraction in US output in decades. The meltdown of the subprime mortgage market in 2007 was at the epicentre of the global financial crisis, which was followed by a deep recession and years of lacklustre ecomomic performance. More generally, the literature has abundantly documented the links between housing market slumps, financial and banking crises and protracted economic recessions (e.g. Detken \& Smets, 2004; European Central Bank [ECB], 2005; Cecchetti, 2008; Claessens, Kose, \& Terrones, 2008; Reinhart \& Rogoff, 2009; International Monetary Fund [IMF], 2011; Jordá, Schularick, \& Taylor, 2014). Hence, it is essential for economists and policymakers to better understand the properties of housing price cycles. Chronologies covering large samples of countries have been established. They show that housing prices generally exhibit long, ample and asymmetric cycles. Girouard, Kennedy, Van den Noord, and André (2006) find that the typical duration of a real housing price cycle in a sample of 18 OECD countries over the period 1970Q1-2005Q1 is around 10 years, roughly similar to that of the business cycle, with which it has been synchronised most of the time, with the notable exception of the early 2000s. The expansion lasts about 23 quarters, during which real housing prices increase by about $45 \%$ and the contraction lasts around 18 quarters, with prices falling by around 25\%. Igan and Loungani (2012) find in a sample of 55 advanced and emerging economies over the period 1970-2010 that the typical expansion lasts 16 quarters with real housing prices increasing by $37 \%$, while the average contraction lasts 11 quarters with real housing prices falling by $17 \%$.

However, few studies have formally tested for asymmetry in aggregate housing prices. Against this background, this paper investigates asymmetry in housing price series for the 50 US states plus the District of Columbia and 381 metropolitan statistical areas (MSAs) using monthly Freddie Mac House Price Indices spanning the period 1975:1-2015:6. The choice of this dataset is motivated by

*Corresponding author. E-mail: rangan.gupta@up.ac.za 
the availability of a large set of high quality, methodologically consistent series, with a wide coverage of the United States. Developments in housing prices tend to vary widely across US states and MSAs. For example, over the past decade or so, the "Sand states" (Arizona, California, Florida, Nevada) experienced dramatic boom-bust cycles, while the housing cycle was muted in large parts of the Midwest. Hence the use of disaggregated data allows a more precise assessment of the extent of asymmetry in the housing price cycle than the use of broad aggregates, which may mask specific market evolutions.

The methodology used for investigating asymmetry in this paper draws on the literature on business cycle asymmetry (Sichel, 1993; Verbrugge, 1997; Razzak, 2001). More specifically, we use the Triples test (Randles et al., 1980), which beyond its traditional use in business cycle analysis, has been used, for example, to test asymmetry in electricity demand in G7 countries (Narayan \& Popp, 2009) and in health expenditure in the United States (Zerihun, Cunado, \& Gupta, 2016). The Triples test has been used by Cook (2006) to investigate asymmetry in UK housing prices. We complement the Triples test results by using the Entropy test of Racine and Maasoumi (2007). While in many cases both tests give similar results, the Entropy test detects more cases of asymmetry. However, some cases of asymmetry are detected by Triples test but not by the Entropy test, justifying the use of both tests. In addition, the Triples test distinguishes between positive and negative asymmetry, which is useful for the economic interpretation of the results.
We investigate both the deepness and steepness of cycles. Deepness measures the relative magnitude of peaks and troughs. Steepness measures the speed at which peaks and troughs are reached. A thorough technical description is provided in the methodological section. But let us provide at this stage a summary description of possible cases of asymmetry and give examples, anticipating on results described below (Figure 1). Positive deepness asymmetry implies that peaks are high, while downturns are relatively mild. Such a pattern can be observed in Connecticut. Negative deepness asymmetry is characterised by modest peaks but deep recessions, as illustrated by Oklahoma. Positive steepness asymmetry indicates rapid increases followed by slower declines in prices, as seen in Hawaii. Negative steepness asymmetry refers to rapid price falls following slower increases, a pattern observed in Georgia. To the best of our knowledge, this is the first paper which carries out an extensive analysis of asymmetry in US housing prices at the regional (states and MSAs) level. The remainder of the paper is organized as follows: Section 1 briefly reviews the literature. Section 2 presents the methodology. Section 3 describes the data. Section 4 discusses the empirical results. Last section concludes.

\section{Brief literature review}

The literature points to a number of factors that can explain the cyclicality of housing prices. First, housing prices are closely related to the business cycle (see André (2010), for evidence from a sample of OECD countries and Leamer
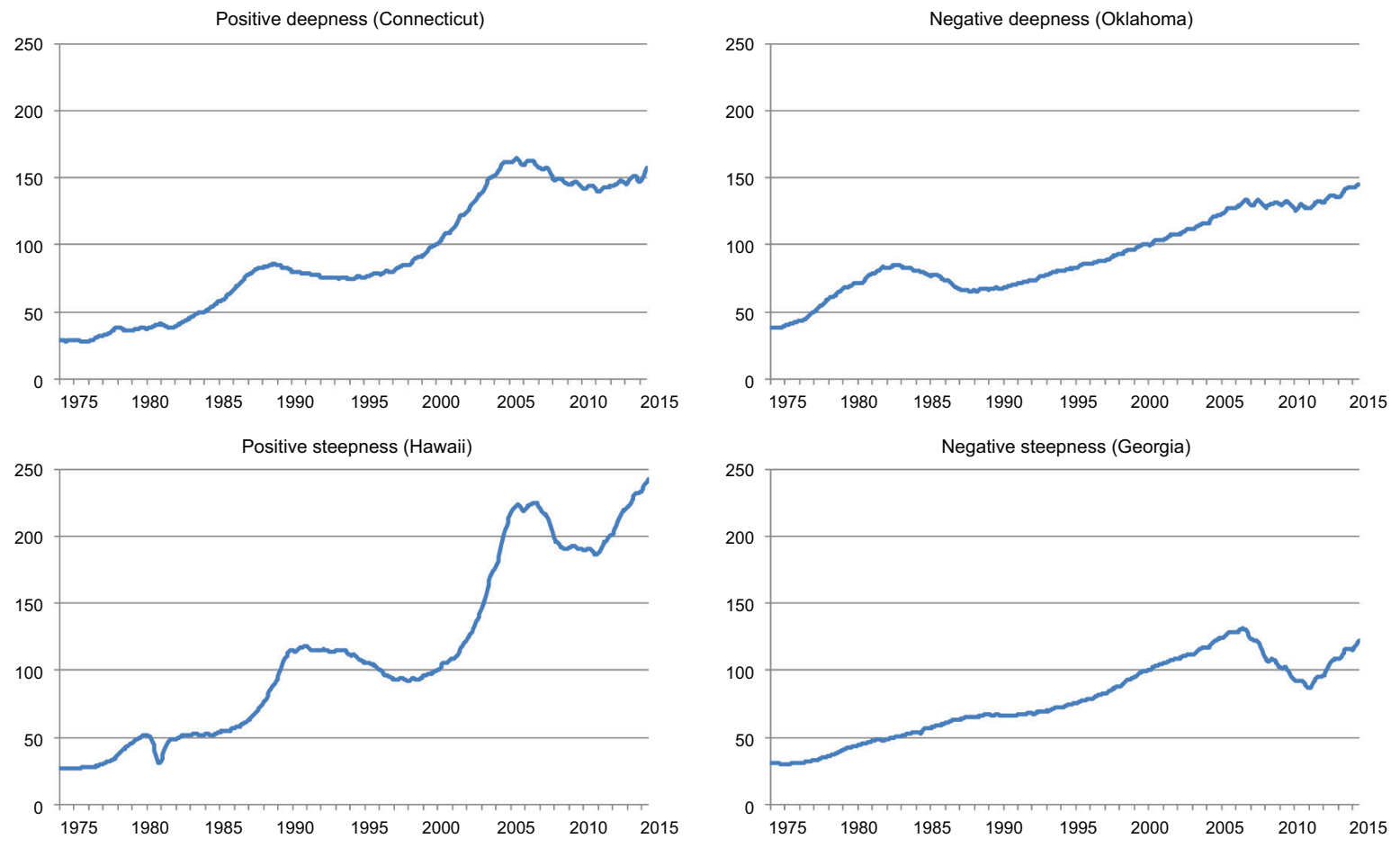

Figure 1. Types of asymmetry: illustrative examples (source: Freddy Mac) 
(2007), for evidence from the United States). Second, the financial cycle is an additional source of housing price fluctuations. While there is no commonly agreed definition of the financial cycle, it can be described as "self-reinforcing interactions between perceptions of value and risk, attitudes towards risk and financing constraints, which translate into booms followed by busts" (Borio, 2012). The financial cycle also relates to the notion of pro-cyclicality of the financial system and the financial accelerator, where increases in credit and in the value of collateral reinforce each other (Kiyotaki \& Moore, 1997; Bernanke, Gertler, \& Gilchrist, 1998; Aoki, Proudman, \& Vlieghe, 2002). Third, cyclicality can be induced by the combination of extrapolative expectations and slow supply responses, which can generate hog-type cycles (André, 2015). Getting construction permits and building homes takes time and there is evidence that the rate of appreciation of housing prices over the preceding four years is a good proxy for the expected rate of housing price increase in several countries (Muellbauer, 2012). Fourth, momentum traders, who believe it is a good time to buy a dwelling because housing prices will rise further, can significantly amplify the housing price cycle (Shiller, 2007; Piazzesi \& Schneider, 2009).

While the cyclicality of housing prices is well documented in the literature, little attention has been paid so far to the statistical properties of housing price cycles. In particular, few studies have formally tested the symmetry of housing price cycles, despite the existence of theoretical reasons for potential asymmetry and the implications for modelling and forecasting. Before reviewing the existing empirical studies on asymmetry and non-linearity in housing prices, a brief discussion of the potential causes of asymmetry is in order. Asymmetry in housing cycles may result from asymmetry in the determinants of housing prices and/or from non-linearity in the relationships between these determinants and housing prices. Determinants of housing cycles may behave in an asymmetric way. The main determinants of housing prices, besides generally relatively slow-moving variables like demographics and the dwelling stock, are household income and mortgage interest rates. Zerihun et al. (2016) find asymmetric behaviour of real per capita personal disposable income in only 7 US states. This is consistent with the general finding of little evidence of asymmetry in aggregate US GDP or GNP (Sichel, 1993; Verbrugge, 1997; Razzak, 2001). Mortgage interest rates seem to behave in a more asymmetric way. This may result from two causes. First, monetary policy reaction functions to inflation and output may be asymmetric. However, empirical support for this hypothesis in the United States is mixed. Dolado, MaríaDolores, and Naveira (2005) find that under certain conditions, the optimal monetary policy is non-linear, with stronger reactions when inflation or output is above target than when they are below target. Nonetheless, they find no asymmetry in the interest rate-setting behaviour of the US Federal Reserve (henceforth, Fed) over the period 19842001. Other studies show that the Fed's reaction function has changed over time. Favero and Rovelli (2003), in a study covering the period 1961-1998, find that the policy preferences of the Fed have changed drastically after 1979. Cukierman and Muscatelli (2008) find evidence of non-linearity in US interest-rate reaction functions, with substantial variations over sub-periods within the sample 1960-2005. Second, several studies on the United States and other countries show the presence of asymmetry in the pass-through from policy rates to bank lending rates. Payne and Waters (2008) find asymmetric pass-through from the federal funds rate to the prime rate over the period 1987-2005. Asymmetric pass-through between policy rates and bank mortgage or other lending rates has also been documented in other countries, including Australia (Lim, 2001; Valadkhani \& Anwar, 2012), Ireland (Goggin, Holton, Kelly, Lydonm, \& McQuinn, 2012) and Switzerland (Cecchin, 2011).

Even in the absence of asymmetry in their determinants, housing prices may display asymmetry as a result of non-linearity in the relationship between housing prices and their determinants. The magnitude and speed of diffusion of economic shocks to housing prices varies across regions because of structural differences in housing markets (Meen, 1999). Ripple effect are often observed in housing markets, as price increases in prime locations induce buyers to move to more affordable areas. In particular, several studies document ripple effects in the United States (Pollakowski \& Ray, 1997; Vansteenkiste, 2007; Canarella, Miller, \& Pollard, 2012; Gupta \& Miller, 2012a, 2012b). In a series of papers, Cook shows that taking asymmetry into account is essential in the analysis of ripple effects and housing price convergence. Using asymmetric unit root tests, he demonstrates that UK housing price adjustments are asymmetric and that taking this feature into account allows identifying widespread housing price convergence across regions (Cook, 2003). He shows that allowing for asymmetry helps detect long-run relationships in UK regional housing prices (Cook, 2005). Analysing cyclical sub-samples, he finds that UK regional housing price convergence is strongest during downturns (Cook, 2012). Cook and Watson (2016) examine the diffusion of changes in housing prices across UK regions over cyclical sub-samples. They find evidence of a ripple effect, especially strong from London to contiguous regions. They also uncover that comovement is strongest during upturns than downturns. Chiang and Tsai (2016), allowing for asymmetry, find ripple effects in US regional housing markets, originating from Los Angeles, New York and Miami. Comovement is again found to be stronger during upswings than downswings. $\mathrm{Wu}, \mathrm{Lu}, \mathrm{Chen}$, and $\mathrm{Chu}$ (2017) also find that comovement between US regional housing prices is time-dependent, with in particular a fall in correlations in 2006, which is consistent with the previous findings of weaker comovement during downturns than upturns.

The behavioural literature shows that asymmetry in housing prices may result from equity constraints and loss aversion. Stein (1995) highlights the impact of required downpayments for the purchase of homes on 
potential sellers. In depressed markets, liquidity constrained households are reluctant to sell if the downpayment requirement makes them unable to purchase a new home. This may increase the volatility of housing prices relative to standard efficient market settings and account for the positive correlation between housing prices and transactions. Moreover, Stein's model contributes to explaining differences in housing price cycles across states or cities, among which the proportion of households with high loan-to-value ratios differs, affecting downpayment capacities. Loss aversion is another potential explanation for low transaction volumes following price falls. Tversky and Kahneman (1991) show in experimental settings that individuals tend to show loss aversion. Empirical studies support the hypothesis of loss aversion in housing markets. Genesove and Mayer (2001) find evidence of loss aversion in the Boston condominium market in the 1990s. More specifically, they find that condominium owners facing nominal losses set higher asking prices, achieve higher selling prices and exhibit a much lower sale hazard than other sellers. Engelhardt (2003) finds that nominal loss aversion significantly affects household mobility in the United States over the period 1985-1996. Conversely, he finds little evidence that low equity resulting from lower housing prices constrains mobility. Anenberg (2011) finds strong evidence that, in the San Francisco Bay Area real estate market over the period 1988-2005, owners facing nominal losses and those with high loan-to-value ratios sell on average for higher prices than other sellers.

Non-linearity can also be induced by expectations of housing prices, which can generate bubbles. As noted above, expectations tend to be extrapolative. In other words, the lagged appreciation of housing prices acts as a "bubble builder". But at some point the deviation of housing prices from fundamentals acts as a "bubble burster" (Abraham \& Hendershott, 1996; Muellbauer \& Murphy, 2008). Such dynamics are bound to generate asymmetric cycles, especially as events triggering the bursting of a bubble are largely random. Furthermore, Bolt, Demertzis, Diks, Hommes, and Van der Leij (2014) find evidence of heterogeneity in housing price expectations with temporary switching between fundamental-reverting and trendfollowing beliefs in eight countries, including the United States, over the period 1970-2013. They show that a housing market model with heterogenous expectations and endogenous switching between optimistic and pessimistic expectations generates non-linear aggregate price fluctuations with booms and busts triggered by stochastic shocks and strongly amplified by self-fulfilling expectations.

Other potential sources of non-linearity in housing price behaviour have been identified in the literature. For example, Chowdhuri and Maclennan (2014) point to the asymmetric effect of monetary policy on UK housing prices over the period 1980-2012, which they relate to variations in the degree of asymmetric information depending on the state of the economy. Tsai (2013) also finds an asymmetric impact of monetary policy (proxied by money supply) on UK housing prices from 1986 to 2011 and re- lates it to downward price rigidity. Antonakakis, Gupta, and André (2015) show that housing market returns are affected in a non-linear way by economic policy uncertainty.

The empirical literature focussing on linearity tests and relative performances of linear and non-linear models also finds some support for non-linearity in US housing prices. Kim and Bhattacharya (2009) find non-linearity over the period 1969-2004 in US aggregate housing prices and in three of the four Census regions, the exception being the Midwest. Miles (2008) estimates a generalized autoregressive (GAR) model over the period 1979-2005 in five US states - California, Florida, Massachusetts, Ohio and Texas - and performs out-of-sample forecasts of housing prices at a two, five and ten year horizon. He finds that the GAR model significantly improves forecasting performances in states with volatile housing markets, such as California, while they bring little improvement in relatively stable markets, such as Ohio. Balcilar, Gupta, and Miller (2015) find evidence of non-linearity in US aggregate housing prices and the four Census regions over the period 1968-2000. However, they find that linear and non-linear models perform similarly in out-of-sample forecasting at short horizons.

Altogether, there are many reasons which could account for asymmetry in housing price cycles. Nevertheless, the literature investigating asymmetry in aggregate housing price series is quite limited. In particular, few studies have formally tested for asymmetry in aggregate housing prices. Cook (2006) investigates asymmetric behavior in the UK housing market, using national and regional data spanning the period 1973-2004. He performs the Triples test (Randles et al., 1980), which is also used in the present paper. Cook finds extensive asymmetry in UK housing prices, with cyclical peaks typically of greater magnitude than corresponding troughs. Li (2015) finds asymmetry in serial correlation and mean reversion in Californian metropolitan housing prices, specifically downward price rigidity and greater mean reversion during downturns. Canepa and Chini (2016) estimate a generalised smooth transition model on Irish, Spanish, UK and US housing prices to show evidence of dynamic asymmetries in cycles, with expansions at exponential rates and contractions at logarithmic rates, resulting in longer contractions than expansions.

\section{Methodology: the Triples and Entropy tests}

The Triples test was initially developed by Randles et al. (1980). Testing deepness asymmetry requires decomposing the series into trend and cyclical components. In order to do so, the Hodrick-Prescott filter can be used (see for example, Razzak, 2001; Narayan, 2009; Zerihun et al., 2016, amongst others). Steepness is tested using first differenced data.

Formally, the Triples test can be described as follows: let $x_{i}, \ldots, x_{N}$ denote a random sample drawn from $F(\mathrm{x}-\theta)$ where $F(\cdot)$ is a cumulative distribution function for a con- 
tinuous population with $F(0)=\frac{1}{2}$ and $\theta$ is the median of the $x$ population.

$$
f^{*}\left(x_{i}, x_{j}, x_{k}\right)=\left[\begin{array}{l}
\left.\operatorname{sign}\left(x_{i}+x_{j}-2 x_{k}\right)+\operatorname{sign}\left(x_{i}+x_{k}-2 x_{j}\right)+\right]^{3}, \\
\operatorname{sign}\left(x_{j}+x_{k}-2 x_{i}\right)
\end{array}\right]^{2}
$$

where: $\operatorname{sign}(u)=-1,0$ or 1 when $\mathrm{u}$ is equal, greater, or smaller than 0 .

$x_{i}, x_{j}, x_{k}$ forms a right triple if $f^{*}\left(x_{i}, x_{j}, x_{k}\right)=\frac{1}{3}$. Note that $f^{*}\left(x_{i}, x_{j}, x_{k}\right)$ can only assume the values $1 / 3,0,1 / 3$. A left triple is defined as any $\left(x_{i}, x_{j}, x_{k}\right)$ for which $f^{*}\left(x_{i}, x_{j}, x_{k}\right)=\frac{-1}{3}$. When $f^{*}\left(x_{i}, x_{j}, x_{k}\right)=0$, the triple is neither right nor left skewed. This last event, however, has probability zero when sampling from a continuous population. The proposed test statistics is then the $\mathrm{U}$ statistics given by:

$$
\hat{\eta}=\left(\begin{array}{c}
N \\
3
\end{array}\right)^{-1} \sum_{i<j<k} f^{*}\left(x_{i}, x_{j}, x_{k}\right) \text {. }
$$

So that

$\hat{\eta}=\frac{[(\text { number of right triples })-(\text { number of left triples })]}{\left[3\left(\begin{array}{c}N \\ 3\end{array}\right)\right]}$.(3)

It follows from Hoeffding (1948) that this is a U statistics estimate

$E(\hat{\eta})=\eta=\operatorname{Pr}\left\{X_{1}+X_{2}-2 X_{3}>0\right\}-\operatorname{Pr}\left\{X_{1}+X_{2}-2 X_{3}<0\right\}$,

with

$$
\operatorname{var}(\hat{\eta})=\left(\begin{array}{c}
N \\
3
\end{array}\right)^{-1} \sum_{c=1}^{3}\left(\begin{array}{l}
3 \\
c
\end{array}\right)\left(\begin{array}{ll}
N & -3 \\
3 & -c
\end{array}\right) \zeta_{c},
$$

where:

$$
\zeta_{c}=\operatorname{var}\left[f_{c}^{*}\left(x_{1}, \ldots, x_{c}\right)\right],
$$

and

$$
f_{c}^{*}\left(x_{1}, \ldots, x_{c}\right)=E\left[f^{*}\left(x_{1}, \ldots, x_{c}, x_{c+1}, \ldots, x_{3}\right)\right] .
$$

Letting $\sigma_{A}^{2}=9 \zeta_{1}$ and since $\sigma_{N}^{2}=\sigma_{A}^{2}+\sigma(1)$, Randles et al. (1980) use the Slutsky theorem to show that $N^{1 / 2}=(\hat{\eta}-\eta) / \sigma_{A}$ also has a standard normal limiting distribution. The appropriate hypotheses to be tested now need to be discussed. First, note that if the underlying distribution is symmetric, $X_{1}+X_{2}-2 X_{3}$ has the same distribution as $-X_{1}-X_{2}+2 X_{3}$ and therefore, $\eta=0$. Hence $\hat{\eta}$ can be used as a statistic for testing,

$$
H_{0}: \hat{\eta}=0 \text { versus } H_{1}: \hat{\eta} \neq 0
$$

This is a two-sided test, but it can be used as a onesided test. This test is used to test the hypothesis that the distribution is symmetric around the unknown median $\theta$ against a broad class of asymmetric alternatives. The Triples test can be interpreted according to the hypothesis tested in equation (8). Rejecting the null hypothesis implies asymmetry. Failure to reject the null hypothesis implies symmetry.

The simple nature of $f^{*}(\cdot)$ makes $\zeta_{1}, \zeta_{2}$ and $\zeta_{3}$ expressible in terms of probabilities, and thus it is possible to use $\mathrm{U}$ statistics to estimate these quantities consistently as follows:

$$
\begin{aligned}
& \zeta_{1}=\operatorname{var}\left[f_{1}^{*}\left(x_{1}\right)\right] \text { with } f_{1}^{*}\left(x_{1}\right)=E\left[f_{1}^{*}(\cdot)\right] ; \\
& \zeta_{1}=N^{-1} \sum_{i=1}^{N}\left(f_{1}^{*}\left(x_{i}\right)-\hat{\eta}\right)^{2}
\end{aligned}
$$

where:

$$
f_{1}^{*}\left(x_{i}\right)=\left(\begin{array}{c}
N-1 \\
2
\end{array}\right) \sum_{\substack{j<k \\
j \neq i \neq k}} \sum f_{1}^{*}\left(x_{i}, x_{j}, x_{k}\right) .
$$

Similarly,

$$
\zeta_{2}=\frac{1}{\left(\begin{array}{c}
N \\
2
\end{array}\right)} \sum_{j<k} \sum\left(f_{2}^{*}\left(x_{i}, x_{k}\right)-\hat{\eta}\right)^{2}
$$

where:

$$
f_{2}^{*}\left(x_{j}, x_{k}\right)=\frac{1}{N-2} \sum_{\substack{i=1 \\ j \neq i \neq k \\ i \neq k}} \sum f^{*}\left(x_{i}, x_{j}, x_{k}\right),
$$

and

$$
\zeta_{3}=\frac{1}{9}-\hat{\eta}^{2} .
$$

Replacing each with $\zeta_{i}$ and $\hat{\zeta}_{i}$ in the expressions $\sigma_{N}$ and $\sigma_{A}$ gives the estimators $\hat{\sigma}_{N}$ and $\hat{\sigma}_{A}$. Both estimators are consistent because each $\hat{\zeta}_{i}$ is written as a linear combination of $U$ statistics.

To test the hypothesis in (8), the Triples test is defined on the basis of $T_{1}=n^{1 / 2} \hat{\eta} / \hat{\sigma}_{N}$ and an associated test based on $T_{2}=n^{1 / 2} \hat{\eta} / \hat{\sigma}_{A}$ so that they reject $H_{0}$ as $\left|T_{i}\right|>Z_{(\alpha / 2)}, i=1,2$ and $Z_{(\alpha / 2)}$ is as the upper percentile of the standard normal distribution. Note that these tests are asymptotically distribution free provided only that the underlying distribution is not degenerate.

The entropy test of asymmetry described in Racine and Maasoumi (2008) is based on the normalization of the Bhattacharya - Hellinger statistic measure of dependence $S_{p}$ given by:

$$
S_{p}=\frac{1}{2} \int_{-\infty}^{+\infty}\left(f_{1}^{1 / 2}-f_{2}^{1 / 2}\right)^{2} \mathrm{dy},
$$

where: $f_{1}=f(\mathrm{y})$ is the marginal density of a continuous stationary random variable $Y_{i}$, and $f_{2}=f(\hat{y})$ that of $\widehat{Y}_{i} ; \widehat{Y}_{i}$ being a rotation of $Y_{i}$ about its mean i.e. $\widehat{Y}_{i}=-Y_{i}+2 E\left(Y_{i}\right)$. The vector $Y_{i}$ is parametrically asymmetric about the mean if $f(\mathrm{y}) \equiv f(\hat{\mathrm{y}})$ which corresponds to the following test of asymmetry:

$$
H_{0}: f(\mathrm{y})=f(\hat{\mathrm{y}}) \text { for all } \mathrm{y} \text {. }
$$


To obtain an entropy version of this asymmetry test; Racine and Maasoumi $(2007,2008)$ make use of the standard Parzen kernel estimators (see Parzen, 1962) of the statistic $S_{p}$ with a specific number of bootstrap resampling based on Efron (1982)'s methodology. ${ }^{1}$

\section{Data}

The measure of housing prices used in this study is the monthly Freddie Mac house price index (FMHPI) covering the period 1975:01-2015:06. The FMHPI is a repeatsales index covering transactions on one-family detached and townhome properties serving as collateral on loans purchased by Freddy Mac or Fannie Mae. The repeat-sales methodology is widely used to measure housing price changes, particularly in the United States. The most prominent examples are the Federal Housing Finance Agency (FHFA), Standard \& Poor's (S\&P) Case-Shiller and CoreLogic house price indices. By measuring the evolution of the value of the same property between two transactions, the repeat-sales methodology allows to measure price changes holding constant property type and location. A limitation of the procedure is that significant renovation or deterioration of the property may affect price changes. However, in the case of the FMHPI, this problem is mitigated by the exclusion of outliers. The FMHPI includes appraisal values related to refinancing transactions in addition to home sales/purchases, with the restriction that at least one transaction in a pair must be a purchase. Appraisal values may be less accurate than purchase prices. However, the inclusion of refinancing transactions more than quadruples the sample size to over 25 million pairs between 1975 and 2010. Increasing the sample particularly increases the quality of estimates at a disaggregated level. Furthermore, the calculation of the FMHPI accounts for potential systematic deviations between appraisal values and purchase prices. $^{2}$

The main advantage of the FMHPI in the context of this study is that it provides monthly data at the MSA level. A limitation to bear in mind is that the FMHPI only covers transactions associated with conforming loans purchased by Freddy Mac or Fannie Mae. This excludes subprime loans and loans with an amount in excess of the ceiling for conforming loans. Conforming loans account for the vast majority of mortgages. However, in some periods non-conforming loans make a significant share of mortgage originations. For example, at its peak in the middle of the first decade of the new century, subprime mortgages accounted for about $20 \%$ of mortgage originations. While it is unlikely to dramatically affect the shape of the housing price cycle, the exclusion of some transac-

\footnotetext{
1 The $\mathrm{R}$ codes for the implementation of this test are provided in the $n p$ package of the $\mathrm{R}$ software freely available at: http:// www.r-project.org.

2 For more details on the FMHPI, see http://www.freddiemac. com/finance/fmhpi.
}

tions may dampen somewhat the volatility of prices and the amplitude of the cycle over some periods. Conversely, the use of weights based on end of previous year estimated property values in the FMHPI is bound to amplify cycles compared with measures using weights based on numbers of housing units, such as the FHFA index.

Series have been adjusted for seasonality using the standard US Census Bureau X13 ARIMA-SEATS Seasonal Adjustment Program. Series have not been adjusted for inflation, because asymmetry in the behaviour of housing prices is likely to result, at least in part, from nominal rigidities, as suggested by the discussion of loss aversion and equity constraints above. Table 1 provides a summary description of the data. The average housing price monthly growth rate over the sample period is $0.39 \%(4.76 \%$ annualized) for the United States. Prices are volatile, with a standard deviation of $0.48 \%$ and an average absolute deviation from trend of $0.36 \%$. Differences between states and across MSAs in average growth rates and volatility are fairly large.

Table 1. Descriptive statistics

\begin{tabular}{|c|c|c|c|}
\hline & $\begin{array}{c}\text { Average } \\
\text { growth rate }\end{array}$ & $\begin{array}{l}\text { Standard } \\
\text { deviation }\end{array}$ & $\begin{array}{l}\text { Average absolute } \\
\text { deviation from } \\
\text { trend }\end{array}$ \\
\hline \multicolumn{4}{|l|}{ USA } \\
\hline & 0.3884 & 0.4764 & 0.3555 \\
\hline \multicolumn{4}{|l|}{ States } \\
\hline Min & 0.2305 & 0.4388 & 0.3395 \\
\hline $\operatorname{Max}$ & 0.5907 & 1.4410 & 0.8500 \\
\hline Q1 & 0.2960 & 0.5580 & 0.4286 \\
\hline Median & 0.3370 & 0.6644 & 0.5043 \\
\hline Q3 & 0.3825 & 0.8117 & 0.6134 \\
\hline \multicolumn{4}{|l|}{ MSAs } \\
\hline Min & 0.1037 & 0.4022 & 0.3074 \\
\hline $\operatorname{Max}$ & 0.6250 & 1.4786 & 0.9414 \\
\hline Q1 & 0.2650 & 0.5751 & 0.4369 \\
\hline Median & 0.3050 & 0.6708 & 0.5123 \\
\hline Q3 & 0.3548 & 0.8308 & 0.6150 \\
\hline
\end{tabular}

Note: Q1 and Q3 correspond to the first and third quartile of the distribution, respectively. The trend is computed using the Hodrick-Prescott filter, with $\lambda=14,400$.

\section{Results}

The Triples test finds deepness asymmetry in 8 states, amounting to about $16 \%$ of the total (51, including the District of Columbia), and steepness asymmetry in 22 states, or more than $40 \%$ of the total (Table 2 ). ${ }^{3}$ Results at the MSA level are consistent with those at the state level. Evidence of deepness asymmetry is found in about

3 The significance threshold used throughout this paper is $10 \%$, unless otherwise specified. 
$8 \%$ of MSAs (29 out of 381) and steepness asymmetry in about $40 \%$ (154). Positive deepness asymmetry is found in 5 states and 11 MSAs. Negative deepness asymmetry is found in 3 states and 18 MSAs. Steepness asymmetry is more common, with positive cases in 12 states and 55 MSAs and negative cases in 10 states and 100 MSAs. States with asymmetric cycles generally contain a number of MSAs where asymmetry of the same type is found. For example, Massachusetts has 3 MSAs with positive steepness asymmetry, California has 7 MSAs with negative steepness and Michigan has 9. This confirms that asymmetry is not the result of an aggregation artifact.

The varying forms of asymmetry across states and MSAs suggest that different underlying economic factors are at play in different places. The Triples test allows distinguishing positive from negative forms of asymmetry, which provides further insights into the economic interpretation of asymmetry. Positive deepness asymmetry, corresponding to high peaks followed by mild downturns, is mainly found in small states of the North-East of the country (Connecticut, Delaware, Maine and Vermont). In these states, the relative scarcity of land may put a floor on housing prices. The only MSA within these states exhibiting deepness asymmetry is Portland-South Portland (Maine). Positive deepness asymmetry is also found in South Dakota (and its MSA of Sioux Falls), but the amplitude of the cycle there is low (Figure 2). Positive steepness asymmetry is found in 12 states. Half of them are in the densely populated North East, while the others are scattered all over the country, including Hawaii. Evidence of positive steepness asymmetry at the state level is associated with the presence of at least one MSA exhibiting the same property, except in Vermont, where nevertheless one MSA (Burlington-South Burlington) comes close to the $10 \%$ confidence threshold.

Table 2. Housing price asymmetry in

US states according to the Triples test.

Statistically significant at the $10 \%$ confidence level

\begin{tabular}{|l|l|l|l|}
\hline \multicolumn{2}{|c|}{ Deepness } & \multicolumn{2}{c|}{ Steepness } \\
\hline \multicolumn{1}{|c|}{ Positive } & Negative & \multicolumn{1}{|c|}{ Positive } & \multicolumn{1}{c|}{ Negative } \\
\hline Connecticut & Alaska & Connecticut & California \\
Delaware & Oklahoma & Hawaii & Georgia \\
Maine & Wisconsin & Idaho & Illinois \\
South Dakota & & Massachusetts & Louisiana \\
Vermont & & North Dakota & Michigan \\
& & Nebraska & New \\
& & New Jersey & Ohimpshire \\
& & New Mexico & Oregon \\
& & New York & Virginia \\
& & Rhode Island & Wisconsin \\
& & Utah & \\
& & Vermont & \\
\hline
\end{tabular}

Note: Triples test $\mathrm{z}$-statistics and p-values are reported in Table A1.

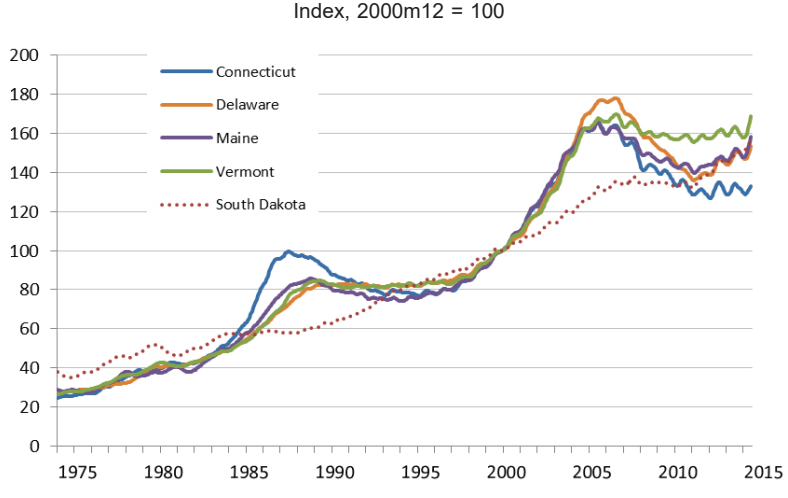

Figure 2. Housing price cycles displaying positive deepness asymmetry (source: Freddy Mac)

Steep downturns are found in several states of the Midwest, where the decline in traditional industries has severely hit the economy. Michigan, Ohio and Wisconsin show negative steepness asymmetry at the $5 \%$ confidence level and Illinois at the 10\% level. In these states, negative steepness asymmetry also appears at the MSA level. Housing prices in Wisconsin, in addition to negative steepness asymmetry, show negative deepness asymmetry. These features are also observed in many of its MSAs. While Midwest states did not experience very sharp increases in housing prices, they suffered steep falls following the latest economic recession (Figure 3).

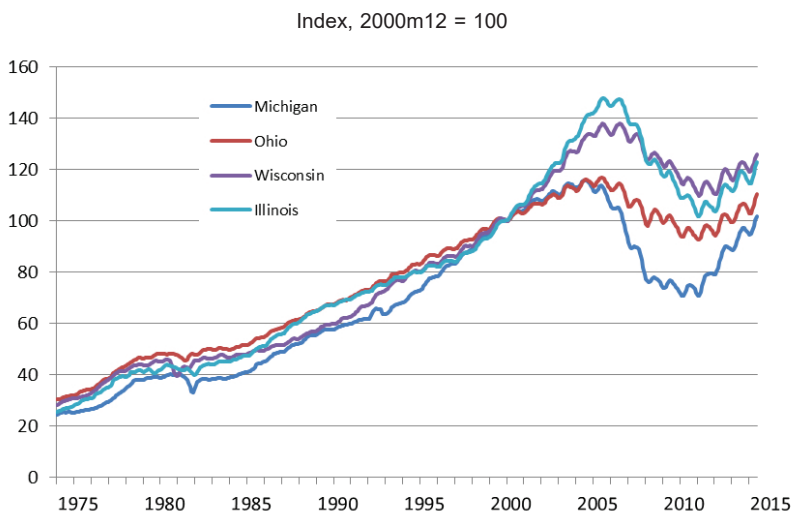

Figure 3. Asymmetric housing price cycles in the Midwest (source: Freddy Mac)

Developments in other states where asymmetry is found seem more idiosyncratic. Negative deepness asymmetry in Alaska and Oklahoma is related to a marked downturn in the late 1980s. Deepness asymmetry is observed in Oklahoma city, but not in MSAs in Alaska. States characterised by positive steepness asymmetry include Hawaii, which has experienced a number of steep increases in housing prices over the sample period, Idaho, which had a housing price spike in the mid-2000s, North Dakota, where the recent oil and gas boom boosted housing prices. Positive steepness asymmetry is also present in Nebraska and New Mexico, but with relatively low amplitude cycles. The latest economic downturn, during 
which prices declined rapidly, drives negative steepness asymmetry in Georgia and Virginia, as well as Oregon. Sharp housing price falls between mid-2006 and mid-2012 largely account for negative steepness asymmetry in California. Furthermore, the expansion of subprime lending during the early 2000s, followed by an abrupt reduction in mortgage credit after the global financial crisis may account for quick falls in housing prices, at least in some parts of the state. The type of steepness asymmetry found in these states is also present in at least one of its MSAs.

The Entropy test does not allow distinguishing between positive and negative forms of asymmetry, which restrains its economic interpretation. However, it detects much more cases of asymmetry than the Triples test (Table 3). Deepness asymmetry is found in 35 states (nearly $70 \%$ of the total) and 226 MSAs (nearly $60 \%$ of the total). Steepness asymmetry is found in 35 states (nearly $70 \%$ of the total) and $228 \mathrm{MSAs}$ (nearly $60 \%$ of the total). As the literature suggests that the Entropy test is more powerful than the Triples test (Racine \& Maasoumi, 2007, 2008), it is possible to conclude that asymmetry in housing prices is the norm. Furthermore, as assuming symmetry when the series display asymmetric behaviour can lead to biased econometric estimates and forecasts, and erroneous economic conclusions, asymmetry should systematically be envisaged when modelling housing prices.

The Entropy test results differ from those of the Triples test for some of the "Sand states" (Arizona, California, Florida, Nevada), which are particularly interesting because they contributed most to the US housing price boom which preceded the Great Recession. Prices skyrocketed in the mid-2000s, but collapsed rapidly after the

Table 3. Summary of asymmetry tests results

\begin{tabular}{|c|c|c|}
\hline & States & \\
\hline \multirow[t]{6}{*}{ Deepness } & Triples test & 8 \\
\hline & Entropy test & $\begin{array}{c}35 \text { (For the states, there are } 43 \\
\text { cases in all of which } 4 \text { cases are } \\
\text { overlapping) }\end{array}$ \\
\hline & MSAs & \\
\hline & Triples test & 29 \\
\hline & Entropy test & $\begin{array}{c}226 \text { (For the MSAs, there are } 255 \\
\text { cases in all of which } 17 \text { cases are } \\
\text { overlapping) }\end{array}$ \\
\hline & States & \\
\hline \multirow[t]{5}{*}{ Steepness } & Triples test & 22 \\
\hline & Entropy test & $\begin{array}{c}35 \text { (For the states, there are } 57 \\
\text { cases in all of which } 17 \text { cases are } \\
\text { overlapping) }\end{array}$ \\
\hline & MSAs & \\
\hline & Triples test & 155 \\
\hline & Entropy test & $\begin{array}{l}228 \text { (For the MSAs, there are } 382 \\
\text { cases in all of which } 126 \text { cases are } \\
\text { overlapping) }\end{array}$ \\
\hline
\end{tabular}

Note: The significance threshold is $10 \%$. Triples test values are reported in Tables A1 and A2. The list of states and MSAs displaying asymmetry is reported in Tables A3 and A4.

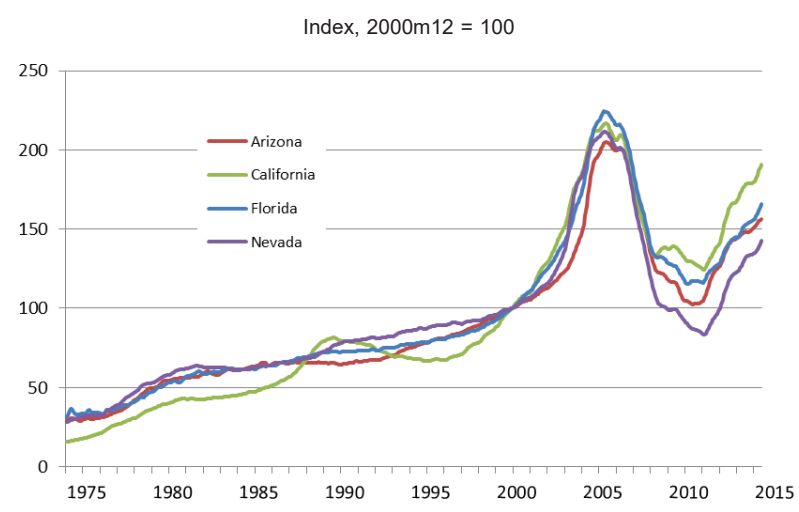

Figure 4. Housing price cycles in the "Sand states" (source: Freddy Mac)

subprime crisis, as over-valuation became obvious, oversupply proved massive and credit dried up (Figure 4). The Triples test found negative steepness asymmetry in California, a result confirmed by the Entropy test, which however also finds deepness in that state. The Entropy test identifies both deepness and steepness asymmetry in Arizona and Nevada. No evidence of asymmetry is found in Florida, which conforms to the Triples test results. However, asymmetry is present in the MSA which includes Miami and a number of other MSAs in Florida, as it is present in the largest MSAs of other "Sand states". A precise characterisation of cyclical patterns is difficult in these states, in part because, except in California, the large boom-bust cycle of the 2000s was preceded by only fairly mild cycles. The rebound in housing prices over the past few years, suggests that cyclicality is here to stay. More observations will be necessary to delineate a cyclical shape, but asymmetry cannot be ruled out.

To sum up, housing cycle asymmetry is found in the majority of US states and MSAs. However, it takes different shapes in different areas, suggesting underlying causes differ. While the most intuitive case of downward rigidity of housing prices, especially related to loss aversion, is widespread, cases where housing price falls are of greater magnitude than increases are also found, predominantly in areas hit by adverse economic shocks. The Triples test results for steepness asymmetry suggest that in many cases housing price adjustments towards troughs are faster than towards peak, indicating that deviations from equilibrium are often corrected in an abrupt way.

\section{Conclusions}

This paper has investigated asymmetry in US housing price cycles at the state and MSA level, using the Triples test (Randles et al., 1980) and the Entropy test of Racine and Maasoumi (2007). Several reasons may account for asymmetry in housing prices, including non-linearity in their determinants and in behavioural responses, in particular linked to equity constraints and loss aversion. However, few studies have formally tested the symmetry of housing price cycles. Both the Triples and the Entropy 
test point to widespread asymmetry in US housing prices, even though the Entropy test detects more cases than the Triples test. In a majority of cases, asymmetry identified by the Triples test is also detected by the Entropy test, but there are some exceptions. Altogether, taking into account the results of both tests, deepness asymmetry is found in 39 of the 51 states (including the District of Columbia) and 238 of the 381 MSAs. Steepness asymmetry is found in 40 states and 257 MSAs. These results imply that potential asymmetry needs to be taken into account when analysing housing price dynamics. In particular, linear models may not provide an adequate description of the data and may display low forecasting performances. The relatively high occurrence of negative steepness asymmetry suggests that linear models may underestimate the likelihood that deviations from equilibrium are corrected in an abrupt way. Potential asymmetry also has consequences for the analysis of comovement and convergence in housing prices, as differences in adjustments over different cycle phases may blur price diffusion patterns.

\section{Acknowledgements}

We would like to thank two anonymous referees for many helpful comments. However, any remaining errors are solely ours. The views expressed in this paper are those of the authors and do not necessarily reflect those of the Organisation for Economic Co-operation and Development (OECD) or the governments of its member countries.

\section{References}

Abraham, J. M., \& Hendershott, P. H. (1996). Bubbles in metropolitan housing markets. Journal of Housing Research, 7(2), 191-207.

André, C. (2010). A bird's eye view of OECD housing markets (OECD Economics Department Working Paper No. 746). Paris: OECD Publishing.

André, C. (2015). Housing cycles: stylised facts and policy challenges. In Proceedings of OeNB Workshops No. 19 (pp. 33-41). Vienna: Oesterreichische Nationalbank.

Anenberg, E. (2011). Loss aversion, equity constraints and seller behaviour in the real estate market. Regional Science and Urban Economics, 41, 67-76.

https://doi.org/10.1016/j.regsciurbeco.2010.08.003

Antonakakis, N., Gupta, R., \& André, C. (2015). Dynamic comovements between economic policy uncertainty and housing market returns. Journal of Real Estate Portfolio Management, 21(1), 53-60.

Aoki, K., Proudman, J., \& Vlieghe, G. (2002). Houses as collateral: has the link between house prices and consumption in the UK changed? Economic Policy Review, 8(1). Retrieved from SSRN: https://ssrn.com/abstract=831805

Balcilar, M., Gupta, R., \& Miller, S. M. (2015). The out-of-sample forecasting performance of nonlinear models of regional housing prices in the US. Applied Economics, 47(22), 22592277. https://doi.org/10.1080/00036846.2015.1005814

Bernanke, B., Gertler, M., \& Gilchrist, S. (1998). The financial accelerator in a quantitative business cycle framework (Working Paper No. 6455). National Bureau of Economic Research.
Bolt, W., Demertzis, M., Diks, C., Hommes, C., \& Van der Leij, M. (2014). Identifying booms and busts in house prices under heterogeneous expectations (De Nederlandsche Bank Working Paper No. 450). Amsterdam.

Borio, C. (2012). The financial cycle and macroeconomics: what have we learnt? (Bank for International Settlememts Working Paper No. 395). Basel.

Canarella, G., Miller, S. M., \& Pollard, S. K. (2012). Unit roots and structural change: an application to US house-price indices. Urban Studies, 49(4), 757-776. https://doi.org/10.1177/0042098011404935

Canepa, A., \& Chini, Z. E. (2016). Dynamic asymmetries in house price cycles: a generalized smooth transition model. Journal of Empirical Finance, 37, 91-103.

https://doi.org/10.1016/j.jempfin.2016.02.011

Cecchetti, S. (2008). Measuring the macroeconomic risks posed by asset price booms. In J. Y. Campbell (Ed.), Asset prices and monetary policy. University of Chicago Press. https://doi.org/10.7208/chicago/9780226092126.003.0002

Cecchin, I. (2011). Mortgage rate pass-through in Switzerland (Swiss National Bank Working Paper No. 2011-8). Zurich.

Chiang, M. C, \& Tsai, I. C. (2016). Ripple effect and contagious effect in the US regional housing markets. The Annals of Regional Science, 56, 55-82. https://doi.org/10.1007/s00168-015-0718-5

Chowdhuri, R. A., \& Maclennan, D. (2014). Asymmetric effects of monetary policy on the UK house prices: A Markov-Switching Vector Autoregression model (MS-VAR), In Housing economics and market analysis. Centre for Housing Research, University of St Andrews.

Claessens, S., Kose, M. A., \& Terrones, M. E. (2008). What happens during recessions, crunches and busts? (International Monetary Fund Working Paper No. 08/274). Washington, DC.

Cook, S. (2003). The convergence of regional house prices in the UK. Urban Studies, 40, 2285-2294. https://doi.org/10.1080/0042098032000123295

Cook, S. (2005). Detecting long-run relationships in regional house prices in the UK. International Review of Applied Economics, 19(1), 107-118. https://doi.org/10.1080/0269217042000312632

Cook, S. (2006). A disaggregated analysis of asymmetrical behaviour in the UK housing market. Urban Studies, 43(11), 2067-2074. https://doi.org/10.1080/00420980600897735

Cook, S. (2012). $\beta$-convergence and the cyclical dynamics of UK regional house prices. Urban Studies, 49(1), 203-218. https://doi.org/10.1177/0042098011399595

Cook, S., \& Watson, D. (2016). A new perspective on the ripple effect in the UK housing market: comovement, cyclical subsamples and alternative indices. Urban Studies, 53(14), 30483062. https://doi.org/10.1177/0042098015610482

Cukierman, A., \& Muscatelli, A. (2008). Non-linear Taylor rules and asymmetric preferences in central banking: evidence from the United Kingdom and the United States. The B.E. Journal of Macroeconomics, 8(1), Article 7.

Detken, C., \& Smets, F. (2004). Asset price booms and monetary policy (Working Paper No. 364). European Central Bank.

Dolado, J. J., María-Dolores, R., \& Naveira, M. (2005). Are monetary-policy reaction functions asymmetric? The role of nonlinearity in the Phillips curve. European Economic Review, 49, 485-503. https://doi.org/10.1016/S0014-2921(03)00032-1

European Central Bank. (2005). Asset price bubbles and monetary policy. In Monthly Bulletin. European Central Bank.

Efron, B. (1982). The Jackknife, the Bootstrap and other resampling plans. In CBMS-NSF Regional Conference Series in Applied Mathematics. Society for Industrial and Applied Mathematics. 
Engelhardt, G. V. (2003). Nominal loss aversion, housing equity constraints, and household mobility: evidence from the United States. Journal of Urban Economics, 53, 171-195. https://doi.org/10.1016/S0094-1190(02)00511-9

Favero, C. A., \& Rovelli, R. (2003). Macroeconomic stability and the preferences of the fed: a formal analysis, 1961-1998. Journal of Money, Credit and Banking, 35(4), 545-556.

https://doi.org/10.1353/mcb.2003.0028

Genesove, D., \& Mayer, C. (2001). Loss aversion and seller behavior: evidence from the housing market. Quarterly Journal of Economics, 116(4), 1233-1260.

https://doi.org/10.1162/003355301753265561

Girouard, N., Kennedy, M., Van den Noord, P., \& André, C. (2006). Recent house price developments: the role of fundamentals (OECD Economics Department Working Papers No. 475). Paris: OECD Publishing.

Goggin, J., Holton, S., Kelly, J., Lydonm, R., \& McQuinn, K. (2012). The financial crisis and the pricing of interest rates in the Irish mortgage market: 2003-2011 (Research Technical Paper No. 1/RT/12). Central Bank of Ireland, Dublin.

Gupta, R., \& Miller, S. M. (2012a). Ripple effects and forecasting home prices in Los Angeles, Las Vegas, and Phoenix. The Annals of Regional Science, 48(3), 763-782. https://doi.org/10.1007/s00168-010-0416-2

Gupta, R., \& Miller, S. M. (2012b). The time series properties of house prices: a case study of the Southern California market. Journal of Real Estate Finance and Economics, 44(3), 339-361. https://doi.org/10.1007/s11146-010-9234-7

Igan, D., \& Loungani, P. (2012). Global housing cycles (International Monetary Fund Working Paper No. 12/217). Washington, DC.

International Monetary Fund. (2011, April). Housing finance and financial stability - back to basics? In Global Financial Stability Report. Washington, DC.

Jordá, Ò., Schularick, M., \& Taylor, A. (2014). The great mortgaging: housing finance, crises, and business cycles (Working Paper No. 20501). National Bureau of Economic Research.

Kim, S. W., \& Bhattacharya, R. (2009). Regional housing prices in the USA: an empirical investigation of nonlinearity. Journal of Real Estate Finance and Economics, 38, 443-460. https://doi.org/10.1007/s11146-007-9094-y

Kiyotaki, N., \& Moore, J. (1997). Credit cycles. Journal of Political Economy, 105(2), 211-248. https://doi.org/10.1086/262072

Leamer, E. E. (2007). Housing is the business cycle. In Economic Policy Symposium - Jackson Hole, Proceedings (pp. 149-233). Federal Reserve Bank of Kansas City.

Li, Y. (2015). The asymmetric house price dynamics: evidence from the California market. Regional Science and Urban Economics, 52, 1-12.

https://doi.org/10.1016/j.regsciurbeco.2015.02.002

Lim, G. C. (2001). Bank interest rate adjustments: are they asymmetric? The Economic Record, 77(237), 135-147. https://doi.org/10.1111/1475-4932.00009

Meen, G. (1999). Regional house prices and the ripple effect: a new interpretation. Housing Studies, 14, 733-753. https://doi.org/10.1080/02673039982524

Miles, W. (2008). Boom-bust cycles and the forecasting performance of linear and non-linear models of house prices. Journal of Real Estate Finance and Economics, 36, 249-264. https://doi.org/10.1007/s11146-007-9067-1

Muellbauer, J. (2012). When is a housing market overheated enough to threaten stability? In A. Heath, F. Packer, \& C. Windsor (Eds.), Property markets and financial stability, proceedings of a conference held in Sydney on 20-21 August. Sydney: Reserve Bank of Australia.
Muellbauer, J., \& Murphy, A. (2008). Housing markets and the economy: the assessment. Oxford Review of Economic Policy, 24(1), 1-33. https://doi.org/10.1093/oxrep/grn011

Narayan, P. K. (2009). Are health expenditures and GDP characterized by asymmetric behaviour? Evidence from 11 OECD countries. Applied Economics, 41, 531-536.

https://doi.org/10.1080/00036840701765304

Narayan, P. K., \& Popp, S. (2009). Can the electricity market be characterised by asymmetric behaviour? Energy Policy, 37, 4364-4372. https://doi.org/10.1016/j.enpol.2009.05.051

Parzen, E. (1962). On estimation of a probability density function and mode. The Annals of Mathematical Statistics, 3, 10651076. https://doi.org/10.1214/aoms/1177704472

Payne, J. E., \& Waters, G. A. (2008). Interest rate pass through and asymmetric adjustment: evidence from the federal funds rate operating target period. Applied Economics, 40(11), 13551362. https://doi.org/10.1080/00036840600806233

Piazzesi, M., \& Schneider, M. (2009). Momentum traders in the housing market: survey evidence and a search model (Working Paper No. 14669). National Bureau of Economic Research.

Pollakowski, H. O., \& Ray, T. S. (1997). Housing price diffusion patterns at different aggregation levels: an examination of housing market efficiency. Journal of Housing Research, 8, 107-124.

Racine, J. S., \& Maasoumi, E. (2007). A versatile and robust metric entropy test of time-reversibility, and other hypotheses. Journal of Econometrics, 138, 547-567. https://doi.org/10.1016/j.jeconom.2006.05.009

Racine, J., \& Maasoumi, E. (2008). A robust entropy-based test of asymmetry for discrete and continuous processes. Econometric Reviews, 28, 246-261. https://doi.org/10.1080/07474930802388066

Randles, R. H., Flinger, M. A., Policello, G. E., \& Wolfe, D. A. (1980). An asymptotically distribution free test for symmetry versus asymmetry. Journal of the American Statistical Association, $75,168-172$.

https://doi.org/10.1080/01621459.1980.10477448

Razzak, W. A. (2001). Business cycle asymmetries: international evidence. Review of Economic Dynamics, 4, 230-243. https://doi.org/10.1006/redy.2000.0109

Reinhart, C. M., \& Rogoff, K. S. (2009). This time is different, eight centuries of financial folly. Princeton, New Jersey: Princeton University Press.

Shiller, R. J. (2007). Understanding recent trends in house prices and home ownership (Working Paper No. 13553). National Bureau of Economic Research.

Sichel, D. E. (1993). Business cycle asymmetry: a deeper look. Economic Inquiry, 31, 224-236.

https://doi.org/10.1111/j.1465-7295.1993.tb00879.x

Stein, J. C. (1995). Prices and trading volume in the housing market: a model with downpayment effects. Quarterly Journal of Economics, 110(2), 379-406. https://doi.org/10.2307/2118444

Tsai, I. C. (2013). The asymmetric impacts of monetary policy on housing prices: a viewpoint of housing price rigidity. Economic Modelling, 31, 405-413.

https://doi.org/10.1016/j.econmod.2012.12.012

Tversky, A., \& Kahneman, D. (1991). Loss aversion in riskless choice: a reference dependent model. Quarterly Journal of Economics, 106, 1039-1061. https://doi.org/10.2307/2937956

Valadkhani, A., \& Anwar, S. (2012). Interest rate pass-through and the asymmetric relationship between the cash rate and the mortgage rate. The Economic Record, 88(282), 341-350. https://doi.org/10.1111/j.1475-4932.2012.00823.x 
Vansteenkiste, I. (2007). Regional housing market spillovers in the US: lessons from regional divergences in a common monetary policy setting (Working Paper No. 708). European Central Bank.

Verbrugge, R. (1997). Investigating cyclical asymmetries. Studies in Nonlinear Dynamics and Econometrics, 2, 15-22.

Wu, Y. L., Lu, C. L., Chen, M. C., \& Chu, F. N. (2017). What forces drive the dynamic interaction between regional hous- ing prices? International Journal of Strategic Property Management, 21(3), 225-239.

https://doi.org/10.3846/1648715X.2016.1254120

Zerihun, M. F., Cunado, J., \& Gupta, R. (2016). Are health care expenditures and personal disposable income characterised by asymmetric behaviour? Evidence from US state-level data. Social Indicators Research, 131(2), 527-542.

https://doi.org/10.1007/s11205-016-1275-8

\section{Appendix}

Table A1. Triples test for US States and national aggregate

\begin{tabular}{|l|c|c|c|c|}
\hline \multirow{2}{*}{ State } & \multicolumn{2}{|c|}{ Steepness } & \multicolumn{2}{c|}{ Deepness } \\
\cline { 2 - 5 } & z-stat & $\mathrm{p}$-value & z-stat & p-value \\
\hline AK & -0.8508 & 0.3949 & -2.324 & 0.0201 \\
\hline AL & -1.5146 & 0.1299 & -0.2401 & 0.8102 \\
\hline AR & -0.5332 & 0.5939 & 0.3783 & 0.7052 \\
\hline AZ & -0.2782 & 0.7809 & -0.6999 & 0.4840 \\
\hline CA & -2.6196 & 0.0088 & 0.4495 & 0.6531 \\
\hline CO & -0.7044 & 0.4812 & 0.2317 & 0.8167 \\
\hline CT & 2.7676 & 0.0056 & 1.8418 & 0.0655 \\
\hline DC & -0.5718 & 0.5675 & -0.1086 & 0.9135 \\
\hline DE & -0.0567 & 0.9548 & 2.3182 & 0.0204 \\
\hline FL & -0.6871 & 0.4920 & -0.6239 & 0.5327 \\
\hline GA & -2.1248 & 0.0336 & 0.5909 & 0.5546 \\
\hline HI & 3.2437 & 0.0012 & 0.5634 & 0.5732 \\
\hline IA & -1.1276 & 0.2595 & -0.7957 & 0.4262 \\
\hline ID & 1.9794 & 0.0478 & 0.4378 & 0.6616 \\
\hline IL & -1.8067 & 0.0708 & -0.0647 & 0.9484 \\
\hline IN & -0.2153 & 0.8295 & -0.2893 & 0.7723 \\
\hline KS & 0.8798 & 0.3790 & 0.4643 & 0.6424 \\
\hline KY & 0.5731 & 0.5666 & -0.1011 & 0.9195 \\
\hline LA & -1.7245 & 0.0846 & 0.1183 & 0.9058 \\
\hline MA & 2.0681 & 0.0386 & -0.5046 & 0.6134 \\
\hline MD & -1.4905 & 0.1361 & 0.5852 & 0.5584 \\
\hline ME & 0.4874 & 0.6260 & 2.6178 & 0.0088 \\
\hline MI & -2.0880 & 0.0368 & -0.1057 & 0.9158 \\
\hline MN & -0.4528 & 0.6507 & -0.9858 & 0.3242 \\
\hline MO & -0.3046 & 0.7606 & 0.1400 & 0.8886 \\
\hline MS & 0.7288 & 0.4661 & 0.8022 & 0.4224 \\
\hline
\end{tabular}

\begin{tabular}{|l|c|c|c|c|}
\hline \multirow{2}{*}{ State } & \multicolumn{2}{|c|}{ Steepness } & \multicolumn{2}{c|}{ Deepness } \\
\cline { 2 - 5 } & z-stat & p-value & z-stat & p-value \\
\hline MT & -0.8562 & 0.3919 & 1.2398 & 0.2151 \\
\hline NC & -1.4510 & 0.1468 & 0.3974 & 0.6911 \\
\hline ND & 2.5718 & 0.0101 & -0.8392 & 0.4013 \\
\hline NE & 2.1131 & 0.0346 & 0.9043 & 0.3658 \\
\hline NH & -2.5398 & 0.0111 & 1.0857 & 0.2776 \\
\hline NJ & 2.1968 & 0.0280 & 1.4534 & 0.1461 \\
\hline NM & 2.7444 & 0.0061 & 1.0244 & 0.3056 \\
\hline NV & -0.0594 & 0.9526 & -0.7370 & 0.4611 \\
\hline NY & 2.5578 & 0.0105 & 1.4764 & 0.1398 \\
\hline OH & -2.0161 & 0.0438 & -0.7845 & 0.4328 \\
\hline OK & -0.6695 & 0.5031 & -2.1182 & 0.0342 \\
\hline OR & -2.4876 & 0.0129 & -0.5604 & 0.5752 \\
\hline PA & 0.2946 & 0.7683 & -0.3782 & 0.7053 \\
\hline RI & 4.5012 & 0.0000 & 0.2126 & 0.8316 \\
\hline SC & -0.5004 & 0.6168 & 0.5650 & 0.5721 \\
\hline SD & -0.6591 & 0.5098 & 2.8492 & 0.0044 \\
\hline TN & 0.7492 & 0.4537 & -0.7916 & 0.4286 \\
\hline TX & 1.2588 & 0.2081 & -0.5374 & 0.5910 \\
\hline UT & 1.7710 & 0.0766 & -0.6483 & 0.5168 \\
\hline VA & -2.0075 & 0.0447 & 0.1069 & 0.9149 \\
\hline VT & 1.9373 & 0.0527 & 1.9037 & 0.0570 \\
\hline WA & 1.0119 & 0.3116 & -0.3026 & 0.7622 \\
\hline WI & -3.2034 & 0.0014 & -2.3822 & 0.0172 \\
\hline WV & -0.5672 & 0.5706 & 0.6601 & 0.5092 \\
\hline WY & -0.0235 & 0.9813 & 0.9006 & 0.3678 \\
\hline USA & -5.6131 & 0.0000 & 1.3669 & 0.1716 \\
\hline
\end{tabular}


Table A2. Triples test for the US MSAs

\begin{tabular}{|c|c|c|c|c|}
\hline \multirow{2}{*}{ City } & \multicolumn{2}{|c|}{ Steepness } & \multicolumn{2}{|c|}{ Deepness } \\
\hline & z-stat & $\mathrm{p}$-value & Z-stat & p-value \\
\hline Abilene, TX & 1.2890 & 0.1974 & 1.5156 & 0.1296 \\
\hline Akron, $\mathrm{OH}$ & -2.5614 & 0.0104 & -0.8398 & 0.401 \\
\hline Albany, GA & -0.7988 & 0.4244 & -0.6314 & 0.5278 \\
\hline Albany, OR & -1.4575 & 0.1450 & -2.3535 & 0.0186 \\
\hline Albany-Schenectady-Troy, NY & 3.2441 & 0.0012 & 2.3811 & 0.0173 \\
\hline Albuquerque, NM & 3.7007 & 0.0000 & 0.1219 & 0.9029 \\
\hline Alexandria, LA & -1.1567 & 0.2474 & -1.0259 & 0.3049 \\
\hline Allentown-Bethlehem-Easton, PA-NJ & 1.3431 & 0.1792 & -0.2412 & 0.8094 \\
\hline Altoona, PA & 0.6472 & 0.5175 & -0.4726 & 0.6365 \\
\hline Amarillo, TX & 0.4210 & 0.6738 & 1.1206 & 0.2625 \\
\hline Ames, IA & -1.1291 & 0.2588 & -0.4359 & 0.6629 \\
\hline Anchorage, AK & -1.0886 & 0.2763 & 0.8846 & 0.3764 \\
\hline Ann Arbor, MI & -1.9511 & 0.0510 & -0.6505 & 0.5154 \\
\hline Anniston-Oxford-Jacksonville, AL & -1.7226 & 0.0850 & -0.6238 & 0.5327 \\
\hline Appleton, WI & -1.4231 & 0.1547 & -1.119 & 0.2631 \\
\hline Asheville, NC & -2.4495 & 0.0143 & -0.5914 & 0.5543 \\
\hline Athens-Clarke County, GA & -0.5927 & 0.5534 & -0.4169 & 0.6767 \\
\hline Atlanta-Sandy Springs-Roswell, GA & -2.2066 & 0.0273 & -0.3228 & 0.7468 \\
\hline Atlantic City-Hammonton, NJ & 4.1726 & 0.0000 & 0.3518 & 0.725 \\
\hline Auburn-Opelika, AL & -3.7128 & 0.0000 & -0.8329 & 0.4049 \\
\hline Augusta-Richmond County, GA-SC & -0.8786 & 0.3796 & -0.5257 & 0.5991 \\
\hline Austin-Round Rock, TX & -2.2274 & 0.0259 & 0.2873 & 0.7739 \\
\hline Bakersfield, CA & 0.9382 & 0.3482 & -1.0017 & 0.3165 \\
\hline Baltimore-Columbia-Towson, MD & -1.5014 & 0.1332 & 0.482 & 0.6298 \\
\hline Bangor, ME & -1.1548 & 0.2482 & 0.7289 & 0.4661 \\
\hline Barnstable Town, MA & 2.4491 & 0.0143 & -0.4557 & 0.6486 \\
\hline Baton Rouge, LA & 0.2864 & 0.7745 & -0.6356 & 0.5251 \\
\hline Battle Creek, MI & -2.2348 & 0.0254 & -0.9152 & 0.3601 \\
\hline Bay City, MI & -3.0674 & 0.0022 & -1.0504 & 0.2935 \\
\hline Beaumont-Port Arthur, TX & 0.8055 & 0.4205 & 1.2745 & 0.2025 \\
\hline Beckley, WV & -1.1712 & 0.2415 & -1.0393 & 0.2987 \\
\hline Bellingham, WA & 2.1329 & 0.0329 & 0.0623 & 0.9503 \\
\hline Bend-Redmond, OR & -2.8275 & 0.0047 & -0.8307 & 0.4061 \\
\hline Billings, MT & -0.0691 & 0.9449 & -0.0965 & 0.9231 \\
\hline Binghamton, NY & 4.4235 & 0.0000 & 0.8953 & 0.3706 \\
\hline Birmingham-Hoover, AL & -1.8415 & 0.0655 & -0.5932 & 0.5531 \\
\hline Bismarck, ND & 2.3743 & 0.0176 & -0.0806 & 0.9357 \\
\hline Blacksburg-Christiansburg-Radford, VA & -2.9398 & 0.0033 & -0.3021 & 0.7626 \\
\hline Bloomington, IL & 0.2921 & 0.7702 & -0.8915 & 0.3727 \\
\hline Bloomington, IN & -1.4789 & 0.1392 & -0.8645 & 0.3873 \\
\hline Bloomsburg-Berwick, PA & -0.3368 & 0.7362 & -0.4656 & 0.6415 \\
\hline Boise City, ID & 1.5448 & 0.1224 & -0.2625 & 0.7929 \\
\hline Boston-Cambridge-Newton, MA-NH & 2.2991 & 0.0215 & -0.3012 & 0.7632 \\
\hline Boulder, CO & 0.5591 & 0.5761 & -0.4863 & 0.6268 \\
\hline Bowling Green, KY & 3.0437 & 0.0023 & -0.2497 & 0.8028 \\
\hline Bremerton-Silverdale, WA & 0.2133 & 0.8311 & -0.4685 & 0.6394 \\
\hline Bridgeport-Stamford-Norwalk, CT & 2.9784 & 0.0029 & 0.1279 & 0.8982 \\
\hline
\end{tabular}


Continued of Table A2

\begin{tabular}{|c|c|c|c|c|}
\hline \multirow{2}{*}{ City } & \multicolumn{2}{|c|}{ Steepness } & \multicolumn{2}{|c|}{ Deepness } \\
\hline & z-stat & $\mathrm{p}$-value & z-stat & $\mathrm{p}$-value \\
\hline Brownsville-Harlingen, TX & 1.5040 & 0.1326 & 1.4092 & 0.1588 \\
\hline Brunswick, GA & -4.6152 & 0.0000 & -0.2459 & 0.8058 \\
\hline Buffalo-Cheektowaga-Niagara Falls, NY & 2.2406 & 0.0251 & 0.761 & 0.4467 \\
\hline Burlington, NC & 0.0119 & 0.9905 & -0.9272 & 0.3538 \\
\hline Burlington-South Burlington, VT & 1.6186 & 0.1055 & 0.3197 & 0.7492 \\
\hline California-Lexington Park, MD & -0.7249 & 0.4685 & 0.3734 & 0.7088 \\
\hline Canton-Massillon, $\mathrm{OH}$ & -2.6604 & 0.0078 & -0.6978 & 0.4853 \\
\hline Cape Coral-Fort Myers, FL & -1.5029 & 0.1329 & -0.9021 & 0.367 \\
\hline Cape Girardeau, MO-IL & 0.1567 & 0.8755 & 1.2485 & 0.2118 \\
\hline Carbondale-Marion, IL & 0.1882 & 0.8507 & -0.7205 & 0.4712 \\
\hline Carson City, NV & 0.2372 & 0.8125 & 0.0074 & 0.9941 \\
\hline Casper, WY & -4.2402 & 0.0000 & 0.718 & 0.4727 \\
\hline Cedar Rapids, IA & -1.6173 & 0.1058 & -0.8998 & 0.3682 \\
\hline Chambersburg-Waynesboro, PA & 3.2757 & 0.0011 & -0.3285 & 0.7425 \\
\hline Champaign-Urbana, IL & 0.8933 & 0.3717 & -0.8392 & 0.4014 \\
\hline Charleston, WV & 0.1296 & 0.8969 & -17.318 & 0.0000 \\
\hline Charleston-North Charleston, SC & 1.0474 & 0.2949 & 17.8223 & 0.0000 \\
\hline Charlotte-Concord-Gastonia, NC-SC & -0.6203 & 0.5351 & -0.5652 & 0.5719 \\
\hline Charlottesville, VA & -2.9269 & 0.0034 & -0.0461 & 0.9632 \\
\hline Chattanooga, TN-GA & -0.8222 & 0.4109 & -0.4323 & 0.6655 \\
\hline Cheyenne, WY & 4.0057 & 0.0000 & 0.6206 & 0.5349 \\
\hline Chicago-Naperville-Elgin, IL-IN-WI & -2.0425 & 0.0411 & -0.7842 & 0.4329 \\
\hline Chico, CA & 0.8393 & 0.4013 & -0.3246 & 0.7455 \\
\hline Cincinnati, OH-KY-IN & -1.8428 & 0.0654 & -0.6951 & 0.487 \\
\hline Clarksville, TN-KY & -1.3383 & 0.1808 & -0.1882 & 0.8507 \\
\hline Cleveland, TN & -1.7166 & 0.0861 & -0.0538 & 0.9571 \\
\hline Cleveland-Elyria, $\mathrm{OH}$ & -2.5110 & 0.0120 & -0.9182 & 0.3585 \\
\hline Coeur d'Alene, ID & 3.4297 & 0.0000 & -0.3042 & 0.761 \\
\hline College Station-Bryan, TX & 2.3414 & 0.0192 & 0.977 & 0.3286 \\
\hline Colorado Springs, CO & -0.5301 & 0.5961 & -0.6656 & 0.5057 \\
\hline Columbia, MO & 0.3589 & 0.7196 & 0.8311 & 0.4059 \\
\hline Columbia, SC & -0.7857 & 0.4320 & -3.0106 & 0.0026 \\
\hline Columbus, GA-AL & -3.3148 & 0.0000 & -0.5494 & 0.5827 \\
\hline Columbus, IN & 1.0991 & 0.2717 & -1.2747 & 0.2024 \\
\hline Columbus, $\mathrm{OH}$ & -1.3557 & 0.1752 & -0.7015 & 0.483 \\
\hline Corpus Christi, TX & 2.0408 & 0.0413 & 1.1082 & 0.2678 \\
\hline Corvallis, OR & -1.9499 & 0.0512 & -0.6563 & 0.5117 \\
\hline Crestview-Fort Walton Beach-Destin, FL & 2.5588 & 0.0105 & -0.5455 & 0.5854 \\
\hline Cumberland, MD-WV & 0.3201 & 0.7489 & 0.0256 & 0.9796 \\
\hline Dallas-Fort Worth-Arlington, TX & 1.9362 & 0.0528 & 0.8359 & 0.4032 \\
\hline Dalton, GA & -2.5019 & 0.0124 & -0.5279 & 0.5976 \\
\hline Danville, IL & -1.5007 & 0.1334 & -1.182 & 0.2372 \\
\hline Daphne-Fairhope-Foley, AL & -3.0270 & 0.0025 & -0.8939 & 0.3714 \\
\hline Davenport-Moline-Rock Island, IA-IL & -1.6811 & 0.0927 & -0.8375 & 0.4023 \\
\hline Dayton, $\mathrm{OH}$ & -1.2170 & 0.2236 & -0.9248 & 0.3551 \\
\hline Decatur, AL & -1.2910 & 0.1967 & -0.899 & 0.3687 \\
\hline Decatur, IL & -1.6874 & 0.0915 & -0.8393 & 0.4013 \\
\hline Deltona-Daytona Beach-Ormond Beach, FL & -1.0902 & 0.2756 & -0.5565 & 0.5779 \\
\hline
\end{tabular}


Continued of Table A2

\begin{tabular}{|c|c|c|c|c|}
\hline \multirow{2}{*}{ City } & \multicolumn{2}{|c|}{ Steepness } & \multicolumn{2}{|c|}{ Deepness } \\
\hline & z-stat & $\mathrm{p}$-value & z-stat & p-value \\
\hline Denver-Aurora-Lakewood, CO & -0.2714 & 0.7861 & -0.4042 & 0.6861 \\
\hline Des Moines-West Des Moines, IA & -0.8200 & 0.4122 & -0.926 & 0.3545 \\
\hline Detroit-Warren-Dearborn, MI & -1.8742 & 0.0609 & -1.1349 & 0.2564 \\
\hline Dothan, AL & -1.6074 & 0.1080 & -0.7266 & 0.4675 \\
\hline Dover, DE & -0.3946 & 0.6931 & -0.4981 & 0.6184 \\
\hline Dubuque, IA & -0.2975 & 0.7661 & -0.7324 & 0.4639 \\
\hline Duluth, MN-WI & -2.4460 & 0.0144 & -0.2217 & 0.8245 \\
\hline Durham-Chapel Hill, NC & -0.2554 & 0.7984 & -0.4999 & 0.6172 \\
\hline East Stroudsburg, PA & -1.5398 & 0.1236 & -0.4901 & 0.6241 \\
\hline Eau Claire, WI & -2.0505 & 0.0403 & -1.0604 & 0.289 \\
\hline El Centro, CA & 0.6703 & 0.5027 & -0.9432 & 0.3456 \\
\hline Elizabethtown-Fort Knox, KY & 0.1295 & 0.8969 & -0.09 & 0.9283 \\
\hline Elkhart-Goshen, IN & 0.2682 & 0.7885 & -1.5831 & 0.1134 \\
\hline Elmira, NY & 4.2836 & 0.0000 & 0.5394 & 0.6137 \\
\hline El Paso, TX & 3.2448 & 0.0012 & 1.5157 & 0.1296 \\
\hline Erie, PA & 0.2658 & 0.7904 & -0.1103 & 0.9122 \\
\hline Eugene, OR & -1.2428 & 0.2140 & -0.6481 & 0.5169 \\
\hline Evansville, IN-KY & 2.2311 & 0.0257 & -1.2215 & 0.2219 \\
\hline Fairbanks, AK & -0.5035 & 0.6146 & 0.6474 & 0.5174 \\
\hline Fargo, ND-MN & 0.7030 & 0.4820 & -0.4834 & 0.6288 \\
\hline Farmington, NM & 0.0472 & 0.9623 & -0.1476 & 0.8827 \\
\hline Fayetteville, NC & -1.4854 & 0.1374 & -0.7609 & 0.4467 \\
\hline Fayetteville-Springdale-Rogers, AR-MO & -2.9924 & 0.0028 & 0.7318 & 0.4643 \\
\hline Flagstaff, AZ & -1.2046 & 0.2283 & -0.0715 & 0.943 \\
\hline Flint, MI & -2.2081 & 0.0272 & -1.1617 & 0.2454 \\
\hline Florence, SC & -1.3083 & 0.1908 & -0.7788 & 0.4361 \\
\hline Florence-Muscle Shoals, AL & -1.0336 & 0.3013 & -0.9749 & 0.3296 \\
\hline Fond du Lac, WI & -2.1743 & 0.0297 & -1.2976 & 0.1944 \\
\hline Fort Collins, CO & 1.2954 & 0.1952 & -0.1047 & 0.9166 \\
\hline Fort Smith, AR-OK & 0.4966 & 0.6195 & 0.802 & 0.4226 \\
\hline Fort Wayne, IN & 1.5434 & 0.1227 & -1.8129 & 0.0698 \\
\hline Fresno, CA & 0.3301 & 0.7413 & -0.5689 & 0.5695 \\
\hline Gadsden, AL & -2.8761 & 0.0040 & -0.6568 & 0.5113 \\
\hline Gainesville, FL & -0.7843 & 0.4329 & -0.5735 & 0.5663 \\
\hline Gainesville, GA & -2.5167 & 0.0118 & -0.4064 & 0.6844 \\
\hline Gettysburg, PA & -1.3756 & 0.1690 & -0.2084 & 0.8349 \\
\hline Glens Falls, NY & 3.4026 & 0.0000 & 0.6296 & 0.5289 \\
\hline Goldsboro, NC & -1.1105 & 0.2668 & -0.7363 & 0.4615 \\
\hline Grand Forks, ND-MN & 1.1604 & 0.2459 & -0.1559 & 0.8761 \\
\hline Grand Island, NE & -0.9832 & 0.3255 & -0.2423 & 0.8086 \\
\hline Grand Junction, CO & -7.5320 & 0.0000 & -0.2398 & 0.8105 \\
\hline Grand Rapids-Wyoming, MI & -2.2748 & 0.0229 & -0.8448 & 0.3982 \\
\hline Grants Pass, OR & -2.1783 & 0.0294 & -0.6196 & 0.5355 \\
\hline Great Falls, MT & 0.8684 & 0.3852 & -0.05 & 0.9602 \\
\hline Greeley, CO & -2.0541 & 0.0400 & -0.5892 & 0.5557 \\
\hline Green Bay, WI & -1.8469 & 0.0648 & -1.1323 & 0.2575 \\
\hline Greensboro-High Point, NC & -0.6724 & 0.5013 & -0.6551 & 0.5124 \\
\hline Greenville, NC & 0.1285 & 0.8978 & -0.6824 & 0.495 \\
\hline
\end{tabular}


Continued of Table A2

\begin{tabular}{|c|c|c|c|c|}
\hline \multirow{2}{*}{ City } & \multicolumn{2}{|c|}{ Steepness } & \multicolumn{2}{|c|}{ Deepness } \\
\hline & z-stat & p-value & z-stat & $\mathrm{p}$-value \\
\hline Greenville-Anderson-Mauldin, SC & 0.6178 & 0.5367 & -1.1819 & 0.2372 \\
\hline Gulfport-Biloxi-Pascagoula, MS & 0.4504 & 0.6524 & 0.8552 & 0.3924 \\
\hline Hagerstown-Martinsburg, MD-WV & -1.9731 & 0.0485 & -0.0608 & 0.9515 \\
\hline Hammond, LA & 1.2951 & 0.1953 & -0.6601 & 0.5092 \\
\hline Hanford-Corcoran, CA & 0.5648 & 0.5722 & -0.534 & 0.5934 \\
\hline Harrisburg-Carlisle, PA & 0.5293 & 0.5966 & -0.3673 & 0.7134 \\
\hline Harrisonburg, VA & -2.3165 & 0.0205 & -0.0761 & 0.9393 \\
\hline Hartford-West Hartford-East Hartford, CT & 3.0651 & 0.0022 & 0.0518 & 0.9587 \\
\hline Hattiesburg, MS & 0.7520 & 0.4520 & 1.3185 & 0.1873 \\
\hline Hickory-Lenoir-Morganton, NC & -7.0856 & 0.0000 & -0.9168 & 0.3593 \\
\hline Hilton Head Island-Bluffton-Beaufort, SC & -1.7112 & 0.0870 & -0.5722 & 0.5672 \\
\hline Hinesville, GA & -0.6396 & 0.5225 & -0.4374 & 0.6618 \\
\hline Homosassa Springs, FL & -0.6011 & 0.5478 & -0.6009 & 0.5479 \\
\hline Hot Springs, AR & -0.5956 & 0.5514 & 0.392 & 0.6951 \\
\hline Houma-Thibodaux, LA & -3.3606 & 0.0000 & -0.499 & 0.6178 \\
\hline Houston-The Woodlands-Sugar Land, TX & -0.2473 & 0.8047 & 1.312 & 0.1895 \\
\hline Huntington-Ashland, WV-KY-OH & -1.2525 & 0.2104 & -1.1271 & 0.2597 \\
\hline Huntsville, $\mathrm{AL}$ & 0.4413 & 0.6590 & -0.4558 & 0.6485 \\
\hline Idaho Falls, ID & 1.4437 & 0.1488 & -0.5011 & 0.6163 \\
\hline Indianapolis-Carmel-Anderson, IN & -0.2365 & 0.8130 & -1.2727 & 0.2031 \\
\hline Iowa City, IA & -0.1837 & 0.8542 & -0.6843 & 0.4938 \\
\hline Ithaca, NY & 3.0805 & 0.0021 & 0.6148 & 0.5387 \\
\hline Jackson, MI & -2.0977 & 0.0359 & -1.3559 & 0.1751 \\
\hline Jackson, MS & 1.1868 & 0.2353 & 1.1366 & 0.2557 \\
\hline Jackson, TN & -1.2641 & 0.2062 & -0.4879 & 0.6256 \\
\hline Jacksonville, FL & -1.7965 & 0.0724 & -0.571 & 0.568 \\
\hline Jacksonville, NC & -1.2612 & 0.2072 & -0.6265 & 0.531 \\
\hline Janesville-Beloit, WI & -1.5658 & 0.1174 & -1.1945 & 0.2323 \\
\hline Jefferson City, MO & 1.0814 & 0.2795 & 1.1459 & 0.2518 \\
\hline Johnson City, TN & -0.3817 & 0.7027 & -13.2276 & 0.0000 \\
\hline Johnstown, PA & -1.3387 & 0.1807 & -0.4828 & 0.6292 \\
\hline Jonesboro, AR & -0.3187 & 0.7500 & 0.7954 & 0.4264 \\
\hline Joplin, MO & 1.4797 & 0.1390 & 1.2609 & 0.2073 \\
\hline Kahului-Wailuku-Lahaina, HI & -1.5182 & 0.1290 & 0.585 & 0.5585 \\
\hline Kalamazoo-Portage, MI & -2.4739 & 0.0134 & -0.8663 & 0.3863 \\
\hline Kankakee, IL & -3.0154 & 0.0026 & -0.5768 & 0.5641 \\
\hline Kansas City, MO-KS & 1.3491 & 0.1773 & 0.4059 & 0.6848 \\
\hline Kennewick-Richland, WA & 0.2442 & 0.8070 & -0.9365 & 0.349 \\
\hline Killeen-Temple, TX & 0.9766 & 0.3288 & 1.1131 & 0.2657 \\
\hline Kingsport-Bristol-Bristol, TN-VA & -0.2071 & 0.8359 & -0.1184 & 0.9058 \\
\hline Kingston, NY & 3.4189 & 0.0000 & 0.485 & 0.6277 \\
\hline Knoxville, TN & -0.3176 & 0.7508 & -0.0607 & 0.9516 \\
\hline Kokomo, IN & -1.0197 & 0.3078 & -1.3589 & 0.1742 \\
\hline La Crosse-Onalaska, WI-MN & -0.6560 & 0.5118 & -0.8399 & 0.401 \\
\hline Lafayette, LA & -3.4763 & 0.0000 & -0.9748 & 0.3297 \\
\hline Lafayette-West Lafayette, IN & -1.1377 & 0.2552 & -1.3099 & 0.1902 \\
\hline Lake Charles, LA & 1.5833 & 0.1134 & -0.6961 & 0.4863 \\
\hline Lake Havasu City-Kingman, AZ & -1.6144 & 0.1064 & -0.0131 & 0.9895 \\
\hline
\end{tabular}


Continued of Table A2

\begin{tabular}{|c|c|c|c|c|}
\hline \multirow{2}{*}{ City } & \multicolumn{2}{|c|}{ Steepness } & \multicolumn{2}{|c|}{ Deepness } \\
\hline & z-stat & $\mathrm{p}$-value & Z-stat & p-value \\
\hline Lakeland-Winter Haven, FL & -0.6075 & 0.5435 & -0.9134 & 0.361 \\
\hline Lancaster, PA & 0.8249 & 0.4095 & -0.3814 & 0.7029 \\
\hline Lansing-East Lansing, MI & -2.5830 & 0.0098 & -1.0101 & 0.3124 \\
\hline Laredo, TX & 1.8237 & 0.0682 & 1.1891 & 0.2344 \\
\hline Las Cruces, NM & 3.0230 & 0.0025 & 0.0098 & 0.9922 \\
\hline Las Vegas-Henderson-Paradise, NV & -0.0988 & 0.9213 & -0.5442 & 0.5863 \\
\hline Lawrence, KS & -1.9444 & 0.0518 & -0.1201 & 0.9044 \\
\hline Lawton, OK & -0.8534 & 0.3934 & -0.7161 & 0.4739 \\
\hline Lebanon, PA & 0.5160 & 0.6058 & -0.5519 & 0.581 \\
\hline Lewiston, ID-WA & 1.0508 & 0.2934 & -0.3073 & 0.7586 \\
\hline Lewiston-Auburn, ME & -0.1895 & 0.8497 & 0.3709 & 0.7107 \\
\hline Lexington-Fayette, KY & 1.4907 & 0.1360 & -0.4051 & 0.6854 \\
\hline Lima, OH & -0.7093 & 0.4781 & -0.9463 & 0.344 \\
\hline Lincoln, NE & 1.6853 & 0.0919 & -0.2056 & 0.8371 \\
\hline Little Rock-North Little Rock-Conway, AR & 0.9074 & 0.3642 & 0.4917 & 0.623 \\
\hline Logan, UT-ID & 2.6831 & 0.0073 & -0.8683 & 0.3852 \\
\hline Longview, TX & 1.6317 & 0.1027 & 0.9466 & 0.3438 \\
\hline Longview, WA & -2.0291 & 0.0424 & -0.8453 & 0.3979 \\
\hline Los Angeles-Long Beach-Anaheim, CA & -2.1515 & 0.0314 & -0.457 & 0.6477 \\
\hline Louisville/Jefferson County, KY-IN & -1.0602 & 0.2890 & -0.0033 & 0.9974 \\
\hline Lubbock, TX & 1.9006 & 0.0574 & 1.1767 & 0.2393 \\
\hline Lynchburg, VA & -2.9756 & 0.0029 & -0.0488 & 0.9611 \\
\hline Macon, GA & -2.8035 & 0.0051 & 0.531 & 0.5954 \\
\hline Madera, CA & 0.0698 & 0.9443 & -1.0345 & 0.3009 \\
\hline Madison, WI & -2.8550 & 0.0043 & -12.5336 & 0.0000 \\
\hline Manchester-Nashua, NH & -3.1215 & 0.0018 & 0.9223 & 0.3564 \\
\hline Manhattan, KS & -0.3452 & 0.7299 & 0.2713 & 0.7862 \\
\hline Mankato-North Mankato, MN & -1.5458 & 0.1222 & -0.228 & 0.8197 \\
\hline Mansfield, $\mathrm{OH}$ & -2.8127 & 0.0049 & -1.2605 & 0.2075 \\
\hline McAllen-Edinburg-Mission, TX & 1.9691 & 0.0489 & 2.943 & 0.0033 \\
\hline Medford, OR & -2.7651 & 0.0057 & -0.2118 & 0.8323 \\
\hline Memphis, TN-MS-AR & 0.0242 & 0.9807 & -1.7773 & 0.0755 \\
\hline Merced, CA & -1.6203 & 0.1052 & -0.0751 & 0.9401 \\
\hline Miami-Fort Lauderdale-West Palm Beach, FL & -0.2261 & 0.8211 & -0.3073 & 0.7587 \\
\hline Michigan City-La Porte, IN & -2.9505 & 0.0032 & 0.037 & 0.9705 \\
\hline Midland, MI & -2.2293 & 0.0258 & 0.7794 & 0.4358 \\
\hline Midland, TX & 3.5009 & 0.0000 & 0.7451 & 0.4562 \\
\hline Milwaukee-Waukesha-West Allis, WI & -3.2061 & 0.0013 & -1.8414 & 0.0656 \\
\hline Minneapolis-St. Paul-Bloomington, MN-WI & -0.1704 & 0.8647 & -1.2229 & 0.2214 \\
\hline Missoula, MT & -0.8504 & 0.3951 & 0.6516 & 0.5146 \\
\hline Mobile, AL & -0.1694 & 0.8655 & -1.4418 & 0.1494 \\
\hline Modesto, CA & -1.6700 & 0.0949 & 0.7255 & 0.4681 \\
\hline Monroe, LA & -1.9474 & 0.0515 & -0.9105 & 0.3625 \\
\hline Monroe, MI & -2.9983 & 0.0027 & -0.1558 & 0.8762 \\
\hline Montgomery, AL & -0.7348 & 0.4625 & -0.4402 & 0.6598 \\
\hline Morgantown, WV & -0.7826 & 0.4339 & -0.616 & 0.5379 \\
\hline Morristown, TN & 2.1225 & 0.0338 & -0.0771 & 0.9386 \\
\hline Mount Vernon-Anacortes, WA & 0.6364 & 0.5245 & -0.1966 & 0.8442 \\
\hline
\end{tabular}


Continued of Table A2

\begin{tabular}{|c|c|c|c|c|}
\hline \multirow{2}{*}{ City } & \multicolumn{2}{|c|}{ Steepness } & \multicolumn{2}{|c|}{ Deepness } \\
\hline & z-stat & $\mathrm{p}$-value & Z-stat & p-value \\
\hline Muncie, IN & -1.4845 & 0.1377 & 0.7834 & 0.4334 \\
\hline Muskegon, MI & -0.5395 & 0.5895 & -1.1858 & 0.2357 \\
\hline Myrtle Beach-Conway-North Myrtle Beach, SC-NC & -1.6350 & 0.1020 & -0.6146 & 0.5388 \\
\hline Napa, CA & -3.1707 & 0.0015 & 0.6256 & 0.5316 \\
\hline Naples-Immokalee-Marco Island, FL & -1.5614 & 0.1184 & 0.4507 & 0.6522 \\
\hline Nashville-Davidson--Murfreesboro--Franklin, TN & 1.8126 & 0.0699 & -0.5172 & 0.605 \\
\hline New Bern, NC & 0.0340 & 0.9729 & 0.5542 & 0.5794 \\
\hline New Haven-Milford, CT & 3.2944 & 0.0000 & 1.2502 & 0.2112 \\
\hline New Orleans-Metairie, LA & -1.8806 & 0.0600 & 0.8241 & 0.4099 \\
\hline New York-Newark-Jersey City, NY-NJ-PA & 1.7778 & 0.0754 & 1.4242 & 0.1544 \\
\hline Niles-Benton Harbor, MI & -4.4644 & 0.0000 & -1.1903 & 0.2339 \\
\hline North Port-Sarasota-Bradenton, FL & -1.3786 & 0.1680 & -0.7338 & 0.4631 \\
\hline Norwich-New London, CT & 1.1581 & 0.2468 & 1.235 & 0.2168 \\
\hline Ocala, FL & -1.1613 & 0.2455 & -1.1393 & 0.2546 \\
\hline Ocean City, NJ & 3.4801 & 0.0000 & 0.5718 & 0.5675 \\
\hline Odessa, TX & 2.9948 & 0.0027 & -0.244 & 0.8073 \\
\hline Ogden-Clearfield, UT & 2.5976 & 0.0094 & -0.4751 & 0.6347 \\
\hline Oklahoma City, OK & -0.3859 & 0.6995 & -2.3283 & 0.0199 \\
\hline Olympia-Tumwater, WA & -0.4959 & 0.6199 & -0.849 & 0.3959 \\
\hline Omaha-Council Bluffs, NE-IA & 1.4906 & 0.1361 & 1.2641 & 0.2062 \\
\hline Orlando-Kissimmee-Sanford, FL & -0.6837 & 0.4941 & -0.75 & 0.4533 \\
\hline Oshkosh-Neenah, WI & -1.8624 & 0.0625 & -2.6952 & 0.007 \\
\hline Owensboro, KY & 3.1576 & 0.0016 & -0.9863 & 0.324 \\
\hline Oxnard-Thousand Oaks-Ventura, CA & -1.3234 & 0.1857 & 0.244 & 0.8072 \\
\hline Palm Bay-Melbourne-Titusville, FL & 0.4551 & 0.6490 & -0.4473 & 0.6546 \\
\hline Panama City, FL & 0.8927 & 0.3720 & -1.2568 & 0.2088 \\
\hline Parkersburg-Vienna, WV & 1.2751 & 0.2023 & 0.1956 & 0.845 \\
\hline Pensacola-Ferry Pass-Brent, FL & 0.3194 & 0.7494 & -0.7851 & 0.4324 \\
\hline Peoria, IL & -3.1193 & 0.0018 & 0.382 & 0.7024 \\
\hline Philadelphia-Camden-Wilmington, PA-NJ-DE-MD & 0.3257 & 0.7446 & 1.1753 & 0.2399 \\
\hline Phoenix-Mesa-Scottsdale, AZ & -0.2853 & 0.7755 & -0.5289 & 0.5968 \\
\hline Pine Bluff, AR & 0.1782 & 0.8586 & 0.5673 & 0.5705 \\
\hline Pittsburgh, PA & 2.1313 & 0.0331 & -0.0178 & 0.9858 \\
\hline Pittsfield, MA & 0.1134 & 0.9097 & 0.1868 & 0.8518 \\
\hline Pocatello, ID & 2.9084 & 0.0036 & 2.3302 & 0.0198 \\
\hline Portland-South Portland, ME & 1.1019 & 0.2705 & 1.8053 & 0.071 \\
\hline Portland-Vancouver-Hillsboro, OR-WA & -1.5692 & 0.1166 & -9.417 & 0.0000 \\
\hline Port St. Lucie, FL & -0.8140 & 0.4156 & -3.3176 & 0.00091 \\
\hline Prescott, AZ & -1.5408 & 0.1234 & -0.4198 & 0.6747 \\
\hline Providence-Warwick, RI-MA & 3.3497 & 0.0000 & 0.2097 & 0.8339 \\
\hline Provo-Orem, UT & 1.1206 & 0.2625 & -0.516 & 0.6059 \\
\hline Pueblo, CO & -1.3275 & 0.1843 & 1.826 & 0.0679 \\
\hline Punta Gorda, FL & -1.4468 & 0.1480 & -0.5772 & 0.5638 \\
\hline Racine, WI & -4.8334 & 0.0000 & -2.5737 & 0.0101 \\
\hline Raleigh, NC & 0.7664 & 0.4434 & 1.7244 & 0.0846 \\
\hline Rapid City, SD & -1.6480 & 0.0994 & 1.5149 & 0.1298 \\
\hline Reading, PA & 0.8831 & 0.3772 & 1.2578 & 0.2085 \\
\hline Redding, CA & 0.2234 & 0.8232 & 0.3855 & 0.6998 \\
\hline
\end{tabular}


Continued of Table A2

\begin{tabular}{|c|c|c|c|c|}
\hline \multirow{2}{*}{ City } & \multicolumn{2}{|c|}{ Steepness } & \multicolumn{2}{|c|}{ Deepness } \\
\hline & z-stat & $\mathrm{p}$-value & z-stat & p-value \\
\hline Reno, NV & 0.6179 & 0.5366 & -1.0087 & 0.3131 \\
\hline Richmond, VA & -2.2430 & 0.0249 & -0.4821 & 0.6297 \\
\hline Riverside-San Bernardino-Ontario, CA & -2.1903 & 0.0285 & 0.1558 & 0.8762 \\
\hline Roanoke, VA & -2.6974 & 0.0070 & -1.0178 & 0.3088 \\
\hline Rochester, MN & 0.0341 & 0.9728 & -1.0936 & 0.2741 \\
\hline Rochester, NY & 2.2456 & 0.0247 & 0.483 & 0.6291 \\
\hline Rockford, IL & -2.9319 & 0.0034 & -1.0246 & 0.3055 \\
\hline Rocky Mount, NC & -1.9876 & 0.0469 & 0.0384 & 0.9694 \\
\hline Rome, GA & -4.2333 & 0.0000 & -1.0725 & 0.2835 \\
\hline Sacramento--Roseville--Arden-Arcade, CA & -1.9009 & 0.0573 & 0.0721 & 0.9425 \\
\hline Saginaw, MI & -3.4549 & 0.0000 & 0.1849 & 0.8533 \\
\hline St. Cloud, MN & -2.0475 & 0.0406 & -0.9904 & 0.322 \\
\hline St. George, UT & 0.8761 & 0.3810 & -0.8325 & 0.4051 \\
\hline St. Joseph, MO-KS & -1.3829 & 0.1667 & 0.9999 & 0.3173 \\
\hline St. Louis, MO-IL & -0.0598 & 0.9523 & -0.1818 & 0.8558 \\
\hline Salem, OR & -1.6606 & 0.0968 & -0.1712 & 0.864 \\
\hline Salinas, CA & -2.1342 & 0.0328 & 0.5255 & 0.5993 \\
\hline Salisbury, MD-DE & -1.0777 & 0.2812 & -0.0122 & 0.9902 \\
\hline Salt Lake City, UT & 1.4956 & 0.1348 & -0.7795 & 0.4357 \\
\hline San Angelo, TX & 3.3209 & 0.0000 & 1.7813 & 0.0749 \\
\hline San Antonio-New Braunfels, TX & 0.6797 & 0.4967 & 1.1786 & 0.2386 \\
\hline San Diego-Carlsbad, CA & -0.3997 & 0.6894 & 0.4538 & 0.65 \\
\hline San Francisco-Oakland-Hayward, CA & -1.4264 & 0.1538 & 1.2091 & 0.2266 \\
\hline San Jose-Sunnyvale-Santa Clara, CA & 0.7877 & 0.4309 & 1.2065 & 0.2276 \\
\hline San Luis Obispo-Paso Robles-Arroyo Grande, CA & 0.2991 & 0.7649 & 0.1056 & 0.9159 \\
\hline Santa Cruz-Watsonville, CA & -1.1327 & 0.2574 & 1.2331 & 0.2175 \\
\hline Santa Fe, NM & -1.6625 & 0.0964 & 0.8796 & 0.3791 \\
\hline Santa Maria-Santa Barbara, CA & -3.5579 & 0.0000 & 0.8846 & 0.3764 \\
\hline Santa Rosa, CA & -1.5300 & 0.1260 & 0.8824 & 0.3776 \\
\hline Savannah, GA & -1.5575 & 0.1194 & -0.0806 & 0.9357 \\
\hline Scranton--Wilkes-Barre--Hazleton, PA & 0.2968 & 0.7666 & -0.6117 & 0.5407 \\
\hline Seattle-Tacoma-Bellevue, WA & 1.5734 & 0.1156 & 0.0748 & 0.9404 \\
\hline Sebastian-Vero Beach, FL & -1.4301 & 0.1527 & -0.0744 & 0.9407 \\
\hline Sebring, FL & -2.1397 & 0.0324 & -0.9948 & 0.3198 \\
\hline Sheboygan, WI & -2.2942 & 0.0218 & -0.6168 & 0.5374 \\
\hline Sherman-Denison, TX & 0.7832 & 0.4335 & 1.0199 & 0.3078 \\
\hline Shreveport-Bossier City, LA & -2.3445 & 0.0191 & -0.362 & 0.7173 \\
\hline Sierra Vista-Douglas, AZ & -0.5881 & 0.5565 & 0.7594 & 0.4476 \\
\hline Sioux City, IA-NE-SD & -0.2095 & 0.8340 & 0.0375 & 0.9701 \\
\hline Sioux Falls, SD & 0.8184 & 0.4131 & 3.1021 & 0.0019 \\
\hline South Bend-Mishawaka, IN-MI & 0.1460 & 0.8839 & -0.8211 & 0.4116 \\
\hline Spartanburg, SC & -1.2086 & 0.2268 & -2.4079 & 0.016 \\
\hline Spokane-Spokane Valley, WA & 0.3720 & 0.7099 & -0.5793 & 0.5624 \\
\hline Springfield, IL & 0.2871 & 0.7740 & -0.8575 & 0.3911 \\
\hline Springfield, MA & 1.6648 & 0.0959 & 0.5656 & 0.5717 \\
\hline Springfield, MO & 0.0861 & 0.9314 & 0.6391 & 0.5228 \\
\hline Springfield, $\mathrm{OH}$ & -2.9955 & 0.0027 & -0.4705 & 0.638 \\
\hline State College, PA & 0.6749 & 0.4998 & 0.0483 & 0.9615 \\
\hline
\end{tabular}


End of Table A2

\begin{tabular}{|c|c|c|c|c|}
\hline \multirow{2}{*}{ City } & \multicolumn{2}{|c|}{ Steepness } & \multicolumn{2}{|c|}{ Deepness } \\
\hline & z-stat & $\mathrm{p}$-value & z-stat & p-value \\
\hline Staunton-Waynesboro, VA & -2.4212 & 0.0155 & -0.4225 & 0.6727 \\
\hline Stockton-Lodi, CA & -3.0645 & 0.0022 & 0.4679 & 0.6398 \\
\hline Sumter, SC & -1.2001 & 0.2301 & 0.5857 & 0.5581 \\
\hline Syracuse, NY & 2.2885 & 0.0221 & -0.9081 & 0.3638 \\
\hline Tallahassee, FL & 0.2053 & 0.8373 & 0.6177 & 0.5368 \\
\hline Tampa-St. Petersburg-Clearwater, FL & -0.6092 & 0.5424 & -0.8141 & 0.4156 \\
\hline Terre Haute, IN & -1.4046 & 0.1601 & -0.0914 & 0.9272 \\
\hline Texarkana, TX-AR & 2.6747 & 0.0075 & -0.5331 & 0.594 \\
\hline The Villages, FL & 1.0998 & 0.2714 & 0.9834 & 0.3254 \\
\hline Toledo, $\mathrm{OH}$ & -3.0712 & 0.0021 & -0.5016 & 0.6159 \\
\hline Topeka, KS & 0.1388 & 0.8896 & -1.8577 & 0.0632 \\
\hline Trenton, NJ & 3.1214 & 0.0018 & 1.4119 & 0.158 \\
\hline Tucson, AZ & -0.0795 & 0.9366 & -0.607 & 0.5438 \\
\hline Tulsa, OK & 0.2273 & 0.8202 & -1.04 & 0.2983 \\
\hline Tuscaloosa, AL & -0.5260 & 0.5989 & 0.5619 & 0.5742 \\
\hline Tyler, TX & 1.9065 & 0.0566 & -0.2412 & 0.8094 \\
\hline Urban Honolulu, HI & 3.7424 & 0.0000 & 0.399 & 0.6899 \\
\hline Utica-Rome, NY & 2.7676 & 0.0056 & 0.5466 & 0.5847 \\
\hline Valdosta, GA & -2.5480 & 0.0108 & 1.0674 & 0.2858 \\
\hline Vallejo-Fairfield, CA & -3.3090 & 0.0000 & 0.2763 & 0.7823 \\
\hline Victoria, TX & 0.1693 & 0.8656 & 1.5051 & 0.1323 \\
\hline Vineland-Bridgeton, NJ & 0.0789 & 0.9371 & -0.0568 & 0.9547 \\
\hline Virginia Beach-Norfolk-Newport News, VA-NC & -0.0416 & 0.9668 & -0.6537 & 0.5133 \\
\hline Visalia-Porterville, CA & 0.7977 & 0.4250 & -0.727 & 0.4672 \\
\hline Waco, TX & 1.4500 & 0.1471 & -0.8627 & 0.3883 \\
\hline Walla Walla, WA & -0.5672 & 0.5706 & 0.8084 & 0.4189 \\
\hline Warner Robins, GA & -2.0141 & 0.0440 & -0.6527 & 0.514 \\
\hline Washington-Arlington-Alexandria, DC-VA-MD-WV & -1.0991 & 0.2717 & 0.3888 & 0.6974 \\
\hline Waterloo-Cedar Falls, IA & -1.7512 & 0.0799 & -1.6639 & 0.0961 \\
\hline Watertown-Fort Drum, NY & 5.5675 & 0.0000 & 1.8065 & 0.0708 \\
\hline Wausau, WI & -2.5290 & 0.0114 & -2.1883 & 0.0286 \\
\hline Weirton-Steubenville, WV-OH & -2.3368 & 0.0194 & -0.5583 & 0.5766 \\
\hline Wenatchee, WA & 0.9975 & 0.3185 & -1.993 & 0.0463 \\
\hline Wheeling, WV-OH & -0.5432 & 0.5870 & 0.2609 & 0.7942 \\
\hline Wichita, KS & 2.1059 & 0.0352 & 2.4434 & 0.0145 \\
\hline Wichita Falls, TX & 1.6916 & 0.0907 & 0.1799 & 0.8572 \\
\hline Williamsport, PA & 0.5138 & 0.6074 & -0.5566 & 0.5778 \\
\hline Wilmington, NC & 0.1330 & 0.8942 & -0.6426 & 0.5205 \\
\hline Winchester, VA-WV & -1.8620 & 0.0626 & -0.7308 & 0.4649 \\
\hline Winston-Salem, NC & -1.4835 & 0.1379 & -0.3948 & 0.693 \\
\hline Worcester, MA-CT & 0.8631 & 0.3881 & 0 & 0.9711 \\
\hline Yakima, WA & 0.0241 & 0.9808 & 0.7176 & 0.473 \\
\hline York-Hanover, PA & 0.2699 & 0.7873 & 0.4219 & 0.6731 \\
\hline Youngstown-Warren-Boardman, OH-PA & -2.0057 & 0.0449 & -0.5766 & 0.5642 \\
\hline Yuba City, CA & -0.4579 & 0.6470 & -0.6603 & 0.5091 \\
\hline Yuma, AZ & -0.5136 & 0.6075 & -0.667 & 0.5048 \\
\hline
\end{tabular}


Table A3. Cases of deepness asymmetry according to the Triples and Entropy tests

\begin{tabular}{|c|c|}
\hline \multicolumn{2}{|l|}{ States } \\
\hline Triples test & Alaska, Connecticut, Delaware, Maine, Oklahoma, South Dakota, Vermont, Wisconsin \\
\hline Entropy test & $\begin{array}{l}\text { Alabama, Arkansas, Arizona, California, Colorado, Connecticut, Georgia, Hawaii, Idaho, Indiana, Kentucky, Lou- } \\
\text { isiana, Massachusetts, Minnesota, Missouri, Mississippi, North Carolina, North Dakota, Nebraska, New Hamp- } \\
\text { shire, New Jersey, New Mexico, Nevada, Ohio, Oklahoma, Oregon, Rhode Island, South Dakota, Tennessee, Texas, } \\
\text { Utah, Virginia, Washington, Wisconsin, USA }\end{array}$ \\
\hline \multicolumn{2}{|r|}{ 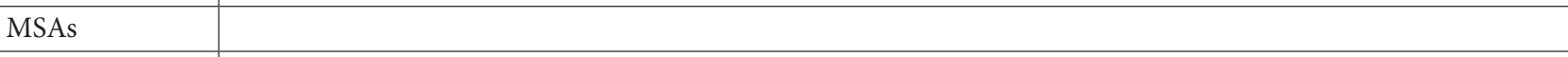 } \\
\hline Triples test & $\begin{array}{l}\text { Albany, OR; Albany-Schenectady-Troy, NY; Charleston, WV; Charleston-North Charleston, SC; Columbia, } \\
\text { SC; Fort Wayne, IN; Johnson City, TN; Madison, WI; McAllen-Edinburg-Mission, TX; Memphis, TN-MS-AR; } \\
\text { Milwaukee-Waukesha-West Allis, WI; Oklahoma City, OK; Oshkosh-Neenah, WI; Pocatello, ID; Portland- } \\
\text { South Portland, ME; Portland-Vancouver-Hillsboro, OR-WA; Port St. Lucie, FL; Pueblo, CO; Racine, WI; Raleigh, } \\
\text { NC; San Angelo, TX; Sioux Falls, SD; Spartanburg, SC; Topeka, KS; Waterloo-Cedar Falls, IA; Watertown-Fort } \\
\text { Drum, NY; Wausau, WI; Wenatchee, WA; Wichita, KS }\end{array}$ \\
\hline Entropy test & 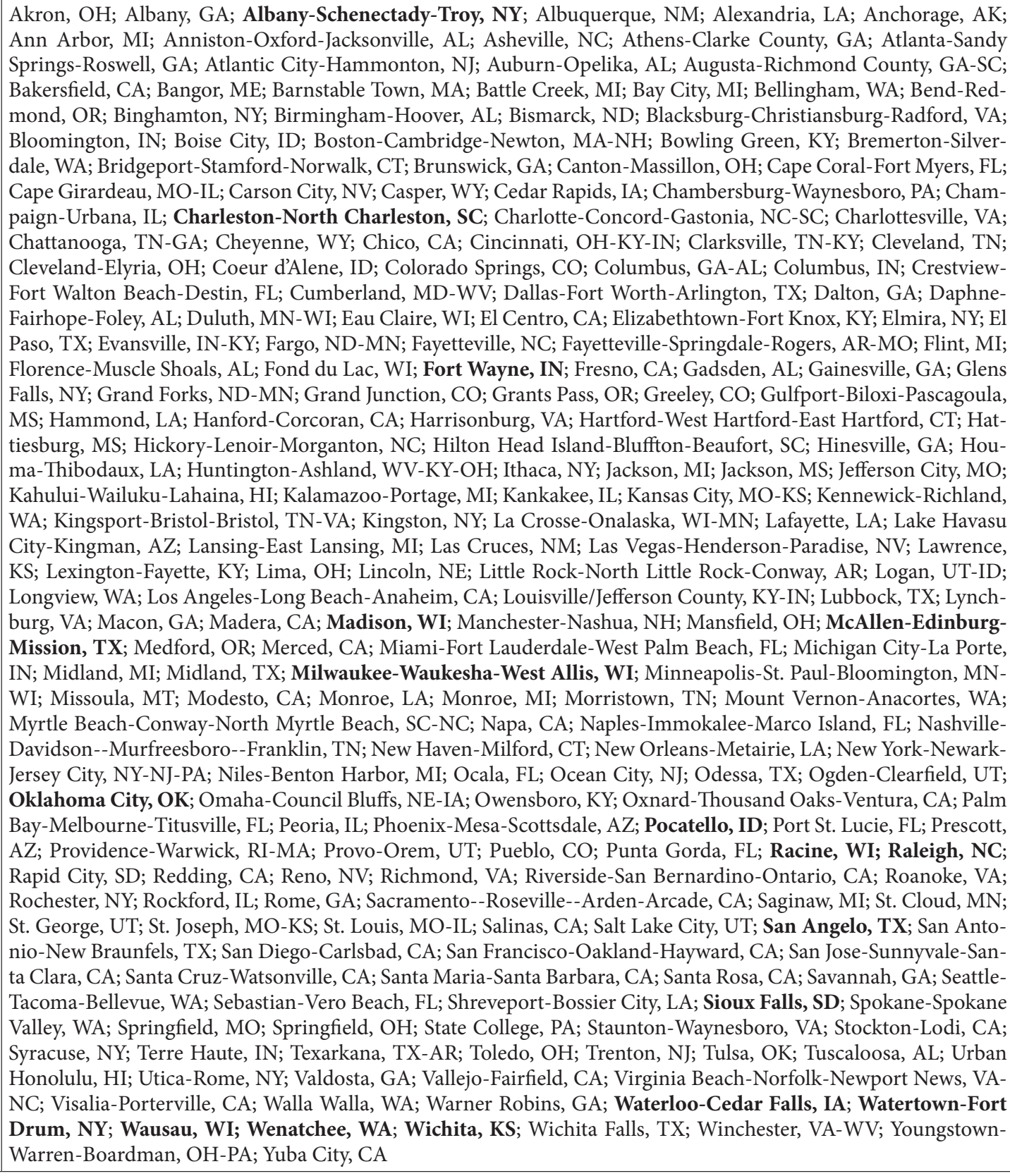 \\
\hline
\end{tabular}


Table A4. Cases of steepness asymmetry according to the Triples and Entropy tests

\begin{tabular}{|c|c|}
\hline \multicolumn{2}{|l|}{ States } \\
\hline Triples test & $\begin{array}{l}\text { Connecticut, California, Hawaii, Georgia, Idaho, Illinois, Massachusetts, Louisiana, North Dakota, Nebraska, New } \\
\text { Jersey, New Mexico, New York, Rhode Island, Utah, Vermont, Michigan, New Hampshire, Ohio, Oregon, Virginia, } \\
\text { Wisconsin }\end{array}$ \\
\hline Entropy test & $\begin{array}{l}\text { Alabama, Arkansas, Arizona, California, Connecticut, Georgia, Hawaii, Idaho, Indiana, Kentucky, Louisiana, Mas- } \\
\text { sachusetts, Minnesota, Missouri, Mississippi, North Carolina, North Dakota, Nebraska, New Hampshire, New Jer- } \\
\text { sey, New Mexico, Nevada, New York, Ohio, Oklahoma, Oregon, Rhode Island, South Dakota, Tennessee, Texas, } \\
\text { Utah, Virginia, Washington, Wisconsin, USA }\end{array}$ \\
\hline \multicolumn{2}{|l|}{ MSAs } \\
\hline Triples test & 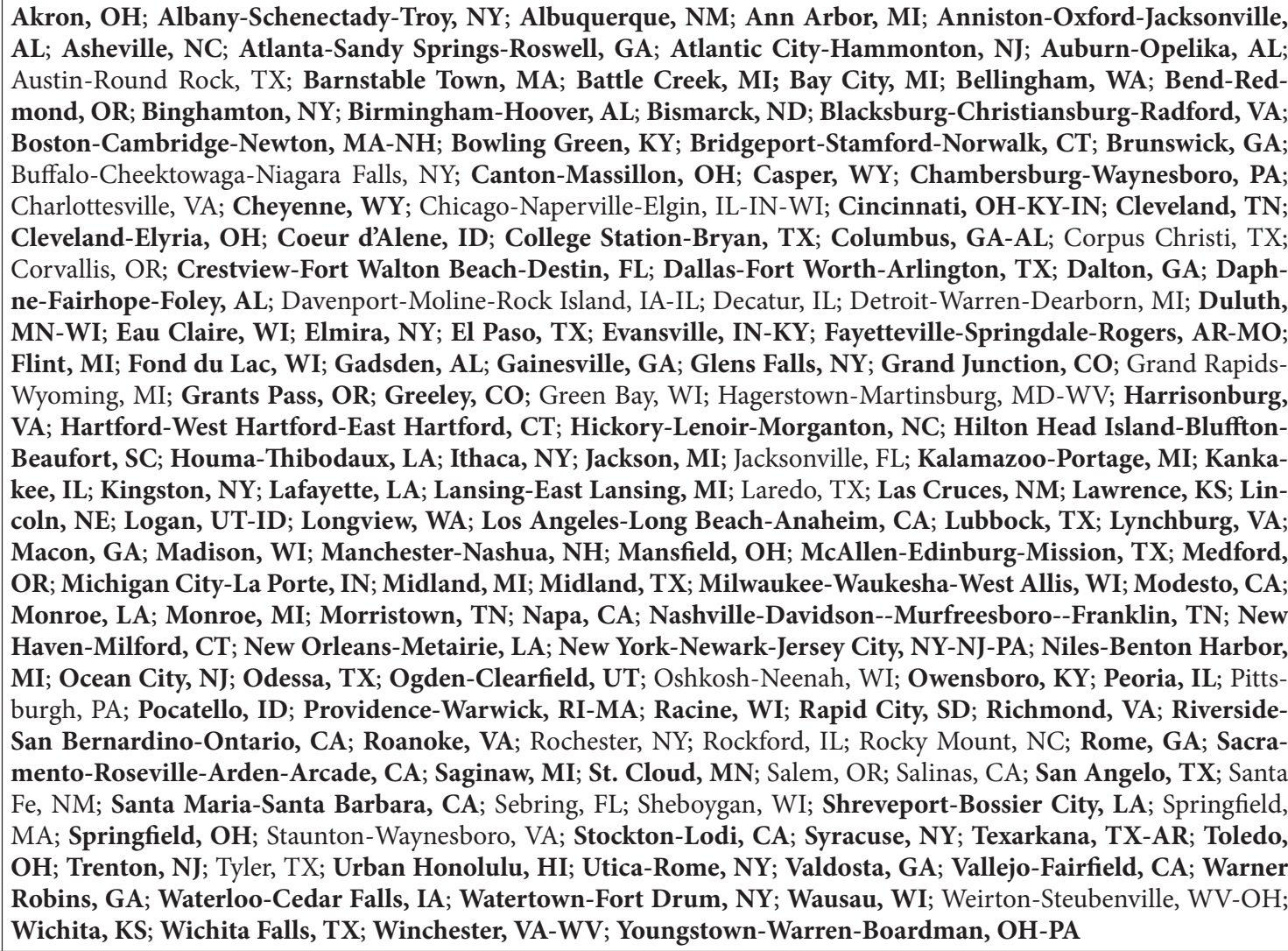 \\
\hline Entropy test & $\begin{array}{l}\text { Akron, OH; Albany-Schenectady-Troy, NY; Albuquerque, NM; Alexandria, LA; Anchorage, AK; Ann Arbor, MI; } \\
\text { Anniston-Oxford-Jacksonville, AL; Asheville, NC; Athens-Clarke County, GA; Atlanta-Sandy Springs-Roswell, } \\
\text { GA; Atlantic City-Hammonton, NJ; Auburn-Opelika, AL; Augusta-Richmond County, GA-SC; Bakersfield, CA; } \\
\text { Bangor, ME; Barnstable Town, MA; Battle Creek, MI; Bay City, MI; Bellingham, WA; Bend-Redmond, OR; Bing- } \\
\text { hamton, NY; Birmingham-Hoover, AL; Bismarck, ND; Blacksburg-Christiansburg-Radford, VA; Bloomington, } \\
\text { IN; Boise City, ID; Boston-Cambridge-Newton, MA-NH; Bowling Green, KY; Bremerton-Silverdale, WA; Bridge- } \\
\text { port-Stamford-Norwalk, CT; Brunswick, GA; Canton-Massillon, OH; Cape Coral-Fort Myers, FL; Cape Girardeau, } \\
\text { MO-IL; Carson City, NV; Casper, WY; Cedar Rapids, IA; Chambersburg-Waynesboro, PA; Champaign-Urbana, } \\
\text { IL; Charleston-North Charleston, SC; Charlotte-Concord-Gastonia, NC-SC; Charlottesville, VA; Chattanooga, TN- } \\
\text { GA; Cheyenne, WY; Chico, CA; Cincinnati, OH-KY-IN; Clarksville, TN-KY; Cleveland, TN; Cleveland-Elyria, } \\
\text { OH; Coeur d'Alene, ID; College Station-Bryan, TX; Colorado Springs, CO; Columbus, GA-AL; Columbus, IN; } \\
\text { Crestview-Fort Walton Beach-Destin, FL; Cumberland, MD-WV; Dallas-Fort Worth-Arlington, TX; Dalton, GA; } \\
\text { Daphne-Fairhope-Foley, AL; Duluth, MN-WI; Eau Claire, WI; El Centro, CA; Elizabethtown-Fort Knox, KY; Elmi- } \\
\text { ra, NY; El Paso, TX; Evansville, IN-KY; Fargo, ND-MN; Fayetteville, NC; Fayetteville-Springdale-Rogers, AR-MO; } \\
\text { Flint, MI; Florence-Muscle Shoals, AL; Fond du Lac, WI; Fort Wayne, IN; Fresno, CA; Gadsden, AL; Gainesville, } \\
\text { GA; Glens Falls, NY; Grand Forks, ND-MN; Grand Junction, CO; Grants Pass, OR; Greeley, CO; Gulfport-Biloxi- } \\
\text { Pascagoula, MS; Hammond, LA; Hanford-Corcoran, CA; Harrisonburg, VA; Hartford-West Hartford-East Hart- } \\
\text { ford, CT; Hattiesburg, MS; Hickory-Lenoir-Morganton, NC; Hilton Head Island-Bluffton-Beaufort, SC; Hinesville, } \\
\text { GA; Houma-Thibodaux, LA; Huntington-Ashland, WV-KY-OH; Ithaca, NY; Jackson, MI; Jackson, MS; Jefferson } \\
\text { City, MO; Kahului-Wailuku-Lahaina, HI; Kalamazoo-Portage, MI; Kankakee, IL; Kansas City, MO-KS; Kenne- } \\
\text { wick-Richland, WA; Kingsport-Bristol-Bristol, TN-VA; Kingston, NY; La Crosse-Onalaska, WI-MN; Lafayette, LA; } \\
\text { Lake Havasu City-Kingman, AZ; Lansing-East Lansing, MI; Las Cruces, NM; Las Vegas-Henderson-Paradise, NV; }\end{array}$ \\
\hline
\end{tabular}


End of Table A4

\begin{tabular}{|c|c|}
\hline States & \\
\hline Entropy test & 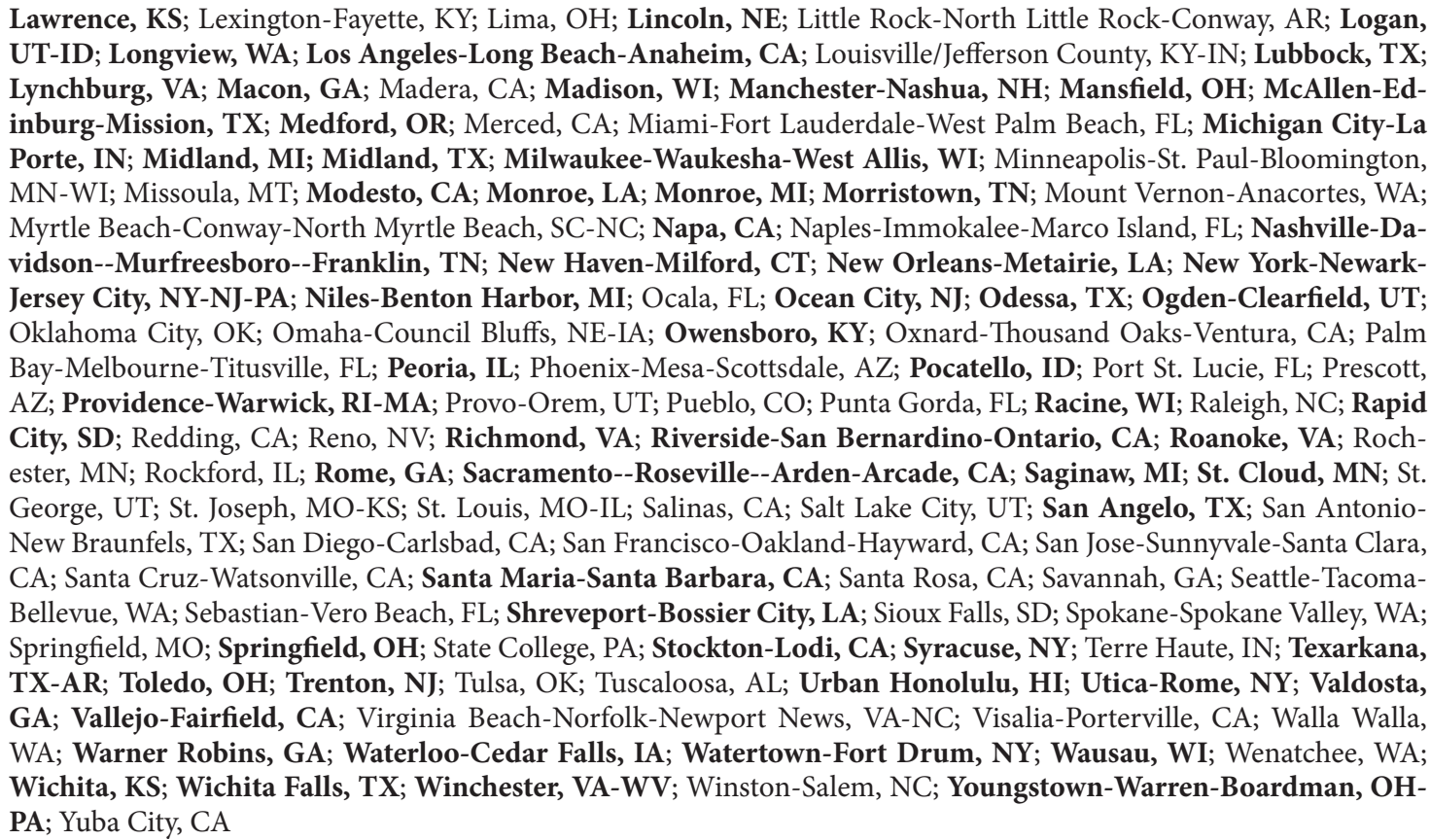 \\
\hline
\end{tabular}

Note: The significance threshold is $10 \%$. 